Т.Е. Савицкая ${ }^{*}$

Коллекция купцов Кокуевых в Саратовском художественном музее имени А.Н. Радищева. К вопросу о реконструкции

doi:10.31518/2618-9100-2021-2-16

УДК 7.074

Выходные данные для цитирования:

Савицкая T.E. Коллекция купцов Кокуевых в Саратовском художественном музее имени А.Н. Радищева. К вопросу о реконструкции // Исторический курьер. 2021. № 2 (16). С. 184-206. URL: http://istkurier.ru/data/2021/ISTKURIER-2021-216.pdf
T.E. Savitskaya*

\section{Merchants Kokuev's Collection in the Saratov Art Museum Named after A.N. Radishchev. In Regards to Reconstruction}

doi:10.31518/2618-9100-2021-2-16

How to cite:

Savitskaya T.E. Merchants Kokuev’s Collection in the Saratov Art Museum Named after A.N. Radishchev. In Regards to Reconstruction // Historical Courier, 2021, No. 2 (16), pp. 184-206. [Available online:] http://istkurier.ru/data/2021/ ISTKURIER-2021-2-16.pdf

Abstract. An important period in the formation of the Radishchev Art Museum collection falls in the early post-revolutionary years. The artworks were flowing, requisitioned mainly from the residents of Saratov and the Saratov province. One of the most significant additions of this time was the collection of merchants Kokuev, who made a significant contribution to the economy, culture, and social life of Saratov in the second half of the $19^{\text {th }}$ - early $20^{\text {th }}$ century. The article identifies the artworks received in 1918 from the Kokuev's house, reveals their compliance with traditional attribution, attempts to reconstruct the original composition of this collection and determine its specific characteristics. It is revealed that a significant amount of the artworks was transferred to other museums and various institutions, however, in most cases, no relevant acts of transferring were found. The remaining items are systematized by the author of the article based on national art styles, as well as types and genres; in the same way, with a question mark - lost artworks, which are difficult to identify. The author divides all items received from the Kokuevs' into three main categories. The first one includes household items, in which we can see the "feminine taste" of the lady of the house, and the second one covers a part of the family chronicles (landscapes depicting memorable for Kokuevs places and family portraits). The actual Kokuevs' "collection" holds items that show their artistic tastes and preferences. Kokuev's passion for Romanticism is clearly visible, and so is their awareness-as members of the enlightened merchant class, they did not chase over-praised famous names but made choices based on a reasonable correlation of price and quality.

Keywords: collection; Kokuev; merchants; Saratov; fine art; Radischev Museum; reconstruction.

The article has been received by the editor on 12.02.2021.

Full text of the article in Russian and references in English are available below.

Аннотация. Важный этап формирования коллекции Саратовского художественного музея им. А.Н. Радищева приходится на первые послереволюционные годы, когда поступают произведения искусства, реквизированные, преимущественно, у жителей Саратова и Саратовской губернии. Одним из наиболее значимых поступлений этого времени стало собрание купцов Кокуевых, внесших большой вклад в экономику, культуру, общественную жизнь Саратова второй половины XIX - начала XX в. В статье идентифицируются поступившие в 1918 г. из дома Кокуевых произведения искусства, выявляется их соответствие традиционной атрибуции, делается попытка реконструировать первоначальный состав

\footnotetext{
* Савицкая Татьяна Евгеньевна, кандидат искусствоведения, Саратовский государственный художественный музей им. А.Н. Радищева, Саратов, Россия, e-mail: sawizkaja@yandex.ru

Savitskaya Tatyana Evgenyevna, Candidate of Art History, Saratov State Art Museum Named after A.N. Radishchev, Saratov, Russia, e-mail: sawizkaja@yandex.ru
} 
данной коллекции, определить ее характерные особенности. Выявляется, что значительная часть предметов была передана в другие музеи и различные учреждения, однако в большинстве случаев соответствующих актов передачи не обнаружено. Сохранившиеся предметы систематизированы автором статьи по национальным школам, а также по видам и жанрам; таким же образом, со знаком вопроса - утраченные произведения, идентификация которых вызывает особые сложности. Все предметы, поступившие от Кокуевых, автором условно разделены на три основные части. Первая - предметы быта, в которых ощутим «женский вкус» хозяйки дома, а вторая - часть семейной хроники (пейзажи с изображением памятных для Кокуевых мест, семейные портреты). Собственно к «коллекции» Кокуевых автор относит предметы, которые показывают их художественные пристрастия. Делается вывод об увлечении Кокуевых искусством романтизма и качественном уровне коллекции представители просвещенного купечества, они не гнались за именами, а руководствовались разумным соответствием цены и качества.

Ключевые слова: коллекция; Кокуевы; купечество; Саратов; изобразительное искусство; Радищевский музей; реконструкция.

Первый общедоступный музей России, Саратовский художественный музей им. А.Н. Радищева, был открыт в 1885 г. В основе его собрания - коллекция А.П. Боголюбова, внука А.Н. Радищева, начинание которого было горячо поддержано общественностью. Среди дарителей музея - представители самых разных сословий и материального достатка: от императора Александра III до разночинцев и крестьян. Однако далеко не все предметы оказались в собрании по доброй воле их прежних владельцев. Важный этап формирования музейной коллекции, как и других отечественных музеев, приходится на первые послереволюционные годы. В 1918-1922 гг. поступают произведения искусства, реквизированные преимущественно у жителей Саратова и Саратовской губернии. Часто они записывались в музейные документы без имени владельца, авторства и принадлежности к национальной школе, размеров и техники, поэтому идентификация этих произведений представляет для исследователей особую сложность. Одним из наиболее значимых поступлений этого времени, пополнивших фонды Радищевского музея, стало собрание купцов Кокуевых.

Задача нашего исследования - идентифицировать поступившие из дома Кокуевых произведения искусства, выявить их соответствие традиционной атрибуции, реконструировать первоначальный состав кокуевской коллекции, определить ее характерные особенности. Это важно для научной каталогизации музейного собрания, а также для изучения истории семьи Кокуевых, внесших значимый вклад в экономику, культуру, общественную жизнь Саратова второй половины XIX - начала XX в.

Начнем с исторической справки. Появились Кокуевы на названной территории, видимо, в середине XIX в. Самым известным членом этой семьи был Павел Иванович Кокуев (18201884), предприниматель, солепромышленник, пароходчик, один из передовых деятелей коммерции своего времени. Именно благодаря его активной деятельности в городе была открыта зерновая оптовая торговая биржа, способствующая торгово-промышленному развитию Саратова (с 1880 г. - председатель Биржевого комитета) ${ }^{1}$. Павел Иванович был одним из самых щедрых жертвователей Саратова - на его средства построено трехэтажное каменное здание Мариинского приюта, которому он и далее оказывал щедрую материальную поддержку. Он проявлял заботу и о благоустройстве города. В частности, в районе Александровской улицы (ныне - имени М. Горького) в 1880-е гг. по его инициативе был сооружен мост, именуемый «кокуевским»². Яркую характеристику Павлу Ивановичу дает в своих воспоминаниях И.Я. Славин (1851-1930), саратовский адвокат и видный обще-

\footnotetext{
${ }^{1}$ Семенов В.Н., Семенов Н.Н. Саратов купеческий. Саратов, 1995. С. 211.

${ }^{2}$ Отдельные упоминания о Кокуевых встречаются во многих публикациях. Наиболее полная информация содержится в статье известного саратовского историка и краеведа Е.К. Максимова: Максимов Е.К. Купцы соль земли саратовской // Саратовские вести по понедельникам. 1999. 5 июля. № 54 (2201). С. 15.
} 
ственный деятель: «бывший откупщик, но вполне окультуренный, с длинными министерскими баками, с барственной осанкой лорда, высокий, видный, представительный, умный и предприимчивый делец; всегда с ласковой приветливой речью в обращении с другими и с мягкими, вкрадчивыми приемами, манерами и жестами, владелец роскошного особнякадворца на Большой Сергиевской улице, честолюбивый и уже достигший значительных успехов в этом направлении: он уже был потомственным почетным гражданином, или даже коммерции советником, и украшен орденами» ${ }^{3}$. «Культурность» П.И. Кокуева подтверждается и тем, что еще в 1868 г. он входил в земскую комиссию по ходатайству об открытии в Саратове университета ${ }^{4}$, а также его интересом к литературе и изобразительному искусству: книги с владельческим штампом «Павел Иванович Кокуев в г. Саратове» до сих пор появляются на художественных аукционах. Так, на аукционе «Гелос» (2010 г.) предлагался сборник Шекспира, поступивший в библиотеку Кокуевых в качестве бесплатной премии к подписке журнала «Живописное обозрение» за 1880 г. ${ }^{5}$

В роскошном доме Кокуевых 6 , расположенном недалеко от пристани, во время путешествия по Волге в 1869 г. останавливался цесаревич Александр Александрович, будущий император Александр III, с молодой супругой и братом, великим князем Алексеем Александровичем ${ }^{7}$.

Сын Павла Ивановича, Николай Павлович (1854-1913/14) - выпускник Земледельческой академии в Вюртемберге (Германия), также потомственный почетный гражданин, известный коллекционер и библиофил (подписчик практически всех российских периодических изданий по искусству ${ }^{8}$ ). С 1889 г. - член Общества любителей изящных искусств (ОЛИИ), созданном при Радищевском музее ${ }^{9}$, один из организаторов и активных участников его первой выставки (апрель 1889 г.), предоставивший для экспонирования принадлежавшие семье предметы искусства ${ }^{10}$, с 1894 г. - член Саратовской ученой архивной комиссии $(\mathrm{CУAK})^{11}$. И он, и его жена Мария Ивановна также занимались благотворительностью.

K представлению об образе жизни семьи, воспитанию детей интересные штрихи добавляют характеристика младшего из Кокуевых, Павла Николаевича и рассказ о трагической судьбе, приведенные в воспоминаниях его сокурсника и друга, историка В.А. Ермолаева. «Воспитанный в оранжерейном духе, он с большим трудом приспосабливался к окружающей жизни. Он был чрезвычайно религиозен, прекрасно знал церковную службу и церковную архитектуру, все церкви Москвы, Ленинграда и других городов, не говоря уж о Саратове, был знаком с архиереями и священниками. <..> Словом, для того времени это был своего рода монстр. Студенты пролетарского происхождения безбожно издевались над ним, и бедный Павлик должен был терпеть их злые шутки. Он прекрасно знал три европейских языка, что сослужило ему в дальнейшем немалую службу. И, будучи студентом, он давал уроки. Это был человек добрый, но наивности необычайной. Про него ходило много анекдотов. Например, он вообразил, что настало время возвратить, хотя бы частично, свою

\footnotetext{
${ }^{3}$ Славин И.Я. Минувшее-пережитое. Воспоминания. Саратов, 2013. С. 76.

${ }^{4}$ Соломонов В., Чернышов А. Цель - университет // Годы и люди. Саратов, 1988. Вып. 3. С. 227. Университет в Саратове был открыт только в 1909 г.

${ }^{5}$ В. Шекспир. Бесплатная премия журнала «Живописное обозрение» за 1880 г. СПб., 1880. [Электронный ресурс]. URL: http://www.gelos.ru/2010/week/29.01/ (дата обращения: 15.12.2011).

${ }^{6}$ Сохранился частично, современный адрес: ул. Чернышевского, 128.

${ }^{7}$ Славин И.Я. Минувшее-пережитое... С. 61-62.

${ }^{8}$ В библиотеке музея хранятся принадлежавшие Н.П. Кокуеву подписки журналов «Мир искусства (1901, 1902, 1904), «Художественные сокровища России» (1901-1907) «Аполлон» (1911); «Русская художественная летопись» (1911), «Старые годы» $(1910,1912,1913,1914)$ и др.

${ }^{9}$ Савельева Е.К. Общество любителей изящных искусств в Саратове. Конец XIX начало - XX века // Материалы VI Боголюбовских чтений. Художественные коллекции музеев и традиции собирательства [Электронный ресурс]. URL: http://ogis.sgu.ru/ogis/bogo/mat6/mat6-5.html (дата обращения: 11.10.2020).

${ }^{10}$ Хроника художественной жизни Саратова 1874-1980. По материалам периодической печати. Саратов, 1988. С. 17 (коллекция П.И. Кокуева).

${ }^{11}$ Соколов В.П. 25-летие Саратовской ученой архивной комиссии [Электронный ресурc]. URL: http:// annales.info/rus/small/suak25.htm (дата обращения: 11.10.2020).
} 
недвижимость, и, кажется, начинал ходатайство по этому поводу. Неудивительно, что он «вылетел» из университета уже на втором курсе, чуть ли не самым первым. Он уехал в Москву, там быстро устроился преподавать иностранные языки в каком-то институте, но в тридцатые годы был схвачен, отправлен в места отдаленные, где много принял мук, вернулся в Саратов, женился, посетил раза два меня и затем снова был схвачен, и на этот раз уже не вернулся» ${ }^{12}$.

Начал собирать произведения искусства, видимо, Павел Иванович, а Николай Павлович, скорее всего, унаследовал и пополнил коллекцию отца. Из документов следует, что предметы из дома Кокуевых на Большой Сергиевской, 67 поступили в Радищевский музей в 1918 г. от Марии Ивановны, вдовы Николая Павловича. Примечательно, что они не были реквизированы, а согласно ее заявлению в сентябре 1918 г., переданы добровольно ${ }^{13}$. Видимо, такое решение было принято М.И. Кокуевой из-за опасения насильственной реквизиции органами советской власти, что повлекло бы за собой более плохие последствия, или ограбления - частого явления в те годы. Скорее всего, она просто считала музей наиболее надежным местом хранения имущества семьи - как известно, тогда многие «бывшие» не верили в долговечность нового режима. В апреле 1922 г. она пишет новое заявление, в котором просит проверить сохранность переданного ею имущества, ввиду его «большой художественной ценности для общества и государства».

Рассмотрим документы в хронологическом порядке. Первый - список (точнее, три его варианта, с некоторыми разночтениями) «Предметы, выбранные для Радищевского музея из дома Кокуевых, Б. Сергиевская, 67» ${ }^{14}$. Он, в целом, дает представление о первоначальном составе переданной в музей коллекции. Здесь называются картины и рисунки русских и европейских художников, старинные гравюры, разнообразные вазы, чашки, блюдца (преимущественно частных русских - Гарднера, Кузнецовых, Корниловых, Терехова и Киселевых, но также Императорских фарфорового и стеклянного заводов, иностранных севрского и саксонского заводов, подсвечники, часы, мелкая пластика, флаконы для духов, предметы мебели, люстры, бра, сумочки, ковры персидские и меховые ковры, куски ткани и т.д. Некоторые предметы называются отдельно, иногда с именами художников и/или с названиями/сюжетом («Амазонка Лансере», «Две девушки»), некоторые - суммарно («картины фламандские - 3 шт.», «ящик с терракотой», «папка со старинными гравюрами», «коллекция бокалов и кружек старинных с надписью Штутгарт 19 шт.», «большая коллекция минералов»), без размеров и, как правило, без техники, или же с некорректной формулировкой («картина карандашом», «картины пером итальянских художников» и т.д.).

Из первого списка (л. 7-10), написанного довольно корявым почерком, ясно, что предметы в доме Кокуевых отбирались комиссией, состоящей из двух представителей музея «агента-эксперта» Б.Ф. Андреева-Горского и делопроизводителя, а также понятого (представителя жилищного отдела) и члена Чрезвычайной комиссии. Отбор производился в течение нескольких дней, с 19 ноября по 9 декабря 1918 г., из комнат и со склада. Видно, что члены комиссии старались отобрать ценные предметы, некоторые комнаты описывались повторно, с поправками (на л. 7 записан «стеклянный колпак», на л. 9 - пометка «стеклянный колпак не взят»). Следующий вариант описи сделан, по всей видимости, уже в музее - аккуратным почерком, без повторов, кое-где с комментариями - «коллекция персидских больших и средних ранних ковров очень ценных - 21, бархатных разной величины 8»; «библиотека с редкими библиографическими изданиями русских иностранных, много художественных изданий», «коллекция гравюр старинных французских и английских».

\footnotetext{
${ }^{12}$ Ермолаев В.А. Без гнева и пристрастия. Записки историка. Саратов, 2009. С. 124.

13 Это заявление не сохранилось, о нем сообщается в заявлении от 05.04.1922 с просьбой проверить наличие в фондах музея переданных в 1918 г. предметов: Саратовский государственный художественный музей им. А.Н. Радищева. Отдел хранения архивных материалов. Фонд «Боголюбовское рисовальное училище» и «Саратовский Радищевский музей». Ведомственный архив (СГХМ. ОХАМ. Ф. «БРУ и СРМ». В.А.). Оп. 5. Ед. хр. 2. Л. 8.

${ }^{14}$ СГХМ. ОХАМ. Ф. «БРУ и СРМ» В.А. ОП. 2. Ед. хр. 3. Л. 7-18.
} 
Третий список карандашом, явно сделанный уже после занесения предметов в музейный инвентарь, намного короче. В его начале против каждого предмета в отдельной графе проставлен инвентарный № (не по порядку); в конце - предметы без номеров (отсутствующие в инвентаре); некоторые экспонаты, ошибочно записанные несколько раз, затем вычеркнуты. Видимо, проводилась сверка имеющихся в наличии предметов с занесенными в инвентарь.

Из-за суммарности записей точное число предметов, поступивших от Кокуевых, определить сложно, явно, что их не могло быть менее 200 (без учета гравюр, минералов, фотографий, книг). Однако в инвентарном списке «Предметов из собрания саратовского дворянина Кокуева из дома на Б. Сергиевской», составленном уже в начале 1919 г. $^{15}$, всего 73 номера (см. Приложение). Объяснение этому можно найти, обратившись к истории Радищевского музея ${ }^{16}$.

19 октября 1918 г., всего за месяц до передачи кокуевской коллекции, директором музея был назначен художник А.И. Кравченко (1889-1940). Именно с ним связано преобразование музея, придание ему того облика, который, по сути, сохранился поныне. По язвительному выражению Кравченко, в 1918 г. Радищевский музей напоминал «сундук старой бабушки, где наряду с брюссельскими кружевами лежат валенки - память о горячо любимой няне» ${ }^{17}$. Миссия музея, задуманного А.П. Боголюбовым, прежде всего, как учреждения для обучения и образования художников, изменилась. Была поставлена новая задача - дать музею чисто художественное направление, с соответствующим принципиальным обновлением экспозиции ${ }^{18}$ и собирательской политики. Это преобразование музея пришлось на тяжелейшую зиму 1918-1919 гг. - не работало отопление и не было электричества. Для посетителей было открыто несколько залов на первом этаже в светлое время дня, все остальные помещения были заполнены постоянно прибывавшими, реквизированными вещами, часть которых сразу вводилась в экспозицию. Кокуевское собрание было одним из самых первых, поступивших в начале реорганизации. Принимать, описывать, а также расставлять и развешивать новые экспонаты А.И. Кравченко помогали всего несколько сотрудников. Первичные описи составлялись по чисто формальным признакам (вид, жанр, иногда - автор и примерный размер и т.д., количество предметов).

В те годы в Саратове, как и в других городах, предполагалось открытие нескольких новых музеев, поэтому экспонаты сразу же распределялись с учетом их передачи в Музей изящных искусств Саратовского университета, музей СУАК (Саратовской ученой архивной комиссии), Педагогический музей. Предполагалось открыть два музея на базе самого Радищевского. Он должен был стать музеем старого, классического искусства, тогда как современное искусство (рубежа XIX-XX вв.) планировалось разместить в Музее нового искусства им. В.Э. Борисова-Мусатова. Копии, репродукции, образцы декоративно-прикладного искусства предназначались для художественно-промышленного музея, задачей которого было развитие эстетического вкуса рабочих окраин.

Уже в начале января 1919 г. на одном из заседаний правления СУАК Кравченко поднял вопрос о возможности обмена экспонатами. Его инициатива была поддержана, музей начинает расставаться с «непрофильными» экспонатами, формируется отдельный запасник из произведений для последующих передач ${ }^{19}$ - видимо, туда и были определены не взятые в основной фонд музея, и, соответственно, не включенные в инвентарь «кокуевские» предметы.

\footnotetext{
${ }^{15}$ Собрание Кокуевых записано вторым, вслед за коллекцией П.В. Васильчикова.

${ }^{16}$ Савельева Е.К. Радищевский музей. 1918-1940 // Саратовский Радищевский музей. Факты. События. Люди. Изд. 2-е, испр. и доп. Саратов, 2016. С. 103-157.

${ }^{17}$ Художественные известия. 1918. № 14. 13-15 ноября. С. 11-12. Цит. по: Савельева Е.К. Радищевский музей. 1918-1940... С. 104.

${ }^{18}$ В частности, устаревшая многорядовая, «шпалерная» развеска картин была заменена однорядовой; закрашены сделанные учащимися боголюбовской рисовальной школы росписи потолка и оконных проемов.

${ }^{19}$ Скорее всего, он находился в тройном зале первого этажа, справа от входа (консультация сотрудника Ради щевского музея Е.К. Савельевой).
} 
В 1921 г. в музее проведена большая ревизия, очевидно, в связи с предполагаемым возвращением А.И. Кравченко в Москву. В работе дирекции были выявлены большие недочеты, о чем появилась информация в местной прессе - видимо, с этим было связано заявление М.И. Кокуевой с просьбой проверить наличие переданного ею «хранителю музея Кравченко согласно списку» ценного имущества.

Попытаемся теперь проследить судьбу отдельных предметов этой коллекции, прежде всего произведений живописи, графики, скульптуры.

Сохранившиеся предметы систематизируем по национальным школам, а также по видам и жанрам; таким же образом, со знаком вопроса - утраченные произведения. В связи с тем, что большая часть утраченных предметов не записана в инвентарь, их идентификация вызывает особые сложности.

Сравним данные старого инвентаря и современные атрибуции (см. Приложение). Записи в инвентарной книге музея показывают, что, в отличие от архивных списков, это уже попытки научной каталогизации собрания. Несмотря на все трудности того времени произведения старались записать с обоснованной атрибуцией и информацией о художнике. Примечательно, что расхождений с современной атрибуцией ${ }^{20}$ немного.

Среди картин европейских мастеров выделяется группа из пяти большеформатных пейзажей. Обозначенные в списке как «картины пейзажи большие», они записаны в инвентарь и традиционно считаются в музее работами неизвестных европейских художников XVIII - начала XIX в., характерными образцами интернационального декоративного пейзажа. Сейчас их атрибуция уточнена: две считаются работами европейских художников этого времени - «Рыбаки на озере» ${ }^{21}$ и «Декоративный пейзаж» ${ }^{22}$, два других предположительно отнесены к швейцарской - «Горный пейзаж» ${ }^{23}$ и немецкой школе - «Пейзаж с всадниками» ${ }^{24}$. Национальные черты в большей степени, чем остальным, присущи картине «Коровы на водопое» ${ }^{25}$ (рис. 1). Особенности композиции, а также мягкость и воздушность светотеневых отношений, сближающие живописную технику с акварельной, позволили отнести ее к английскому мастеру. Интернациональный стиль (синтез традиций английской и французской живописи) отличает и значительно меньший по размеру, по сравнению с вышеназванными, романтический пейзаж «Охота», обозначенный в кокуевском списке как работа француза А. Шеффера (1795-1858). Имя этого мастера впоследствии, в результате исследований, было отведено, но работа сохранила принадлежность французской школе ${ }^{26}$.

Из рисунков европейских мастеров сохранилось четыре. «Дворец Флоры»- типичная работа французского художника и садового архитектора Ф.Ж. Беланже (1745-1818) ${ }^{27}$, сочетавшего архитектуру с ландшафтными видами (рис. 2). В инвентаре точно повторена надпись на старой этикетке: “Belanger Architecte. Palais de Flore” - подтверждение того, что сюда тщательно переносились подписи и надписи, для нас важна эта информация при поиске и идентификации утраченных предметов.

\footnotetext{
${ }^{20}$ Подробные аргументы современной атрибуции приведены в генеральном каталоге: Саратовский государственный художественный музей имени А.Н. Радищева. М., 2004. Т. 1. Русская живопись XVIII-XIX вв.; Саратов, 2008. Т. 2. Зарубежное искусство. Живопись, рисунок, скульптура, шпалеры: каталог.

${ }^{21}$ Неизвестный европейский художник конца XVIII в. Рыбаки на озере. Холст, масло. 95 × 134 . Инв. № Ж-1063 (ст. инв. № 1063).

${ }^{22}$ Неизвестный европейский художник конца XVIII в. Декоративный пейзаж. Холст, масло. $106 \times 161,5$. Инв. № Ж-627 (ст. инв. № 6354).

${ }^{23}$ Неизвестный художник конца XVIII в. Швейцария (?). Горный пейзаж. Холст, масло. 105 × 140. Инв. № Ж-1011. (ст. инв. № 6355).

${ }^{24}$ Неизвестный художник начала XIX в. Германия, Пейзаж с всадниками. Холст, масло. 96,5 × 135,5. Инв. № Ж-526 (ст. инв. № 6352).

${ }^{25}$ Неизвестный художник начала ХІХ в. Англия. Коровы на водопое. Холст, масло. 103,5 × 153,5. Инв. № Ж-1010 (ст. инв. № 6356).

${ }^{26}$ Неизвестный художник середины ХІХ в. Франция. Охота. Холст, масло. 22 × 44,5. Инв. № Ж-927 (ст. инв. № 6377).

${ }^{27}$ Беланже Ж.Ф. Дворец Флоры. Бумага, перо черным, кисть коричневым тоном. 19,5 × 28 . Инв. № Г-867 (ст. инв. № 6360).
} 


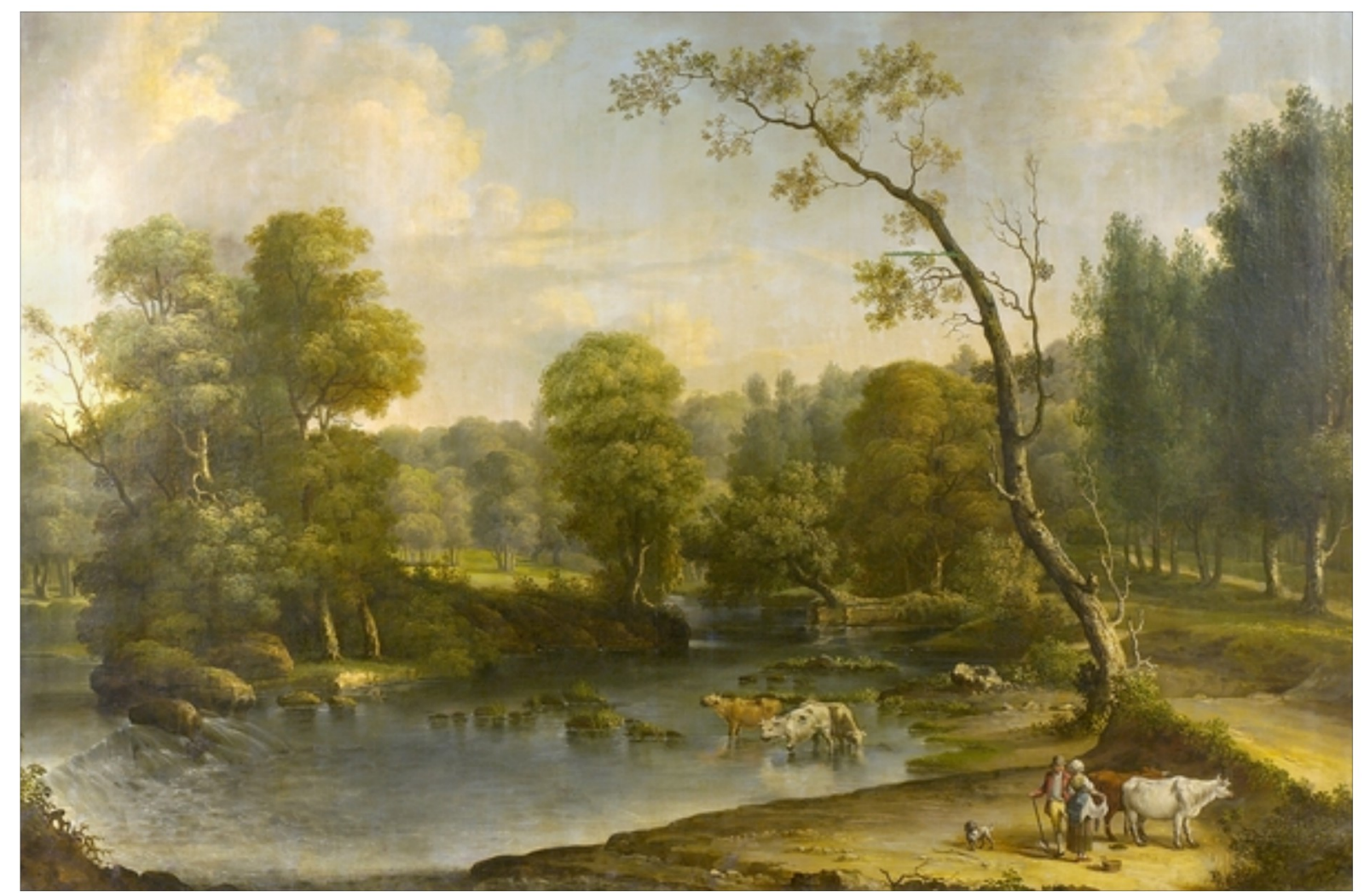

Puc. 1. Неизвестный художник начала XIX в. Англия. Коровы на водопое. Холст, масло.

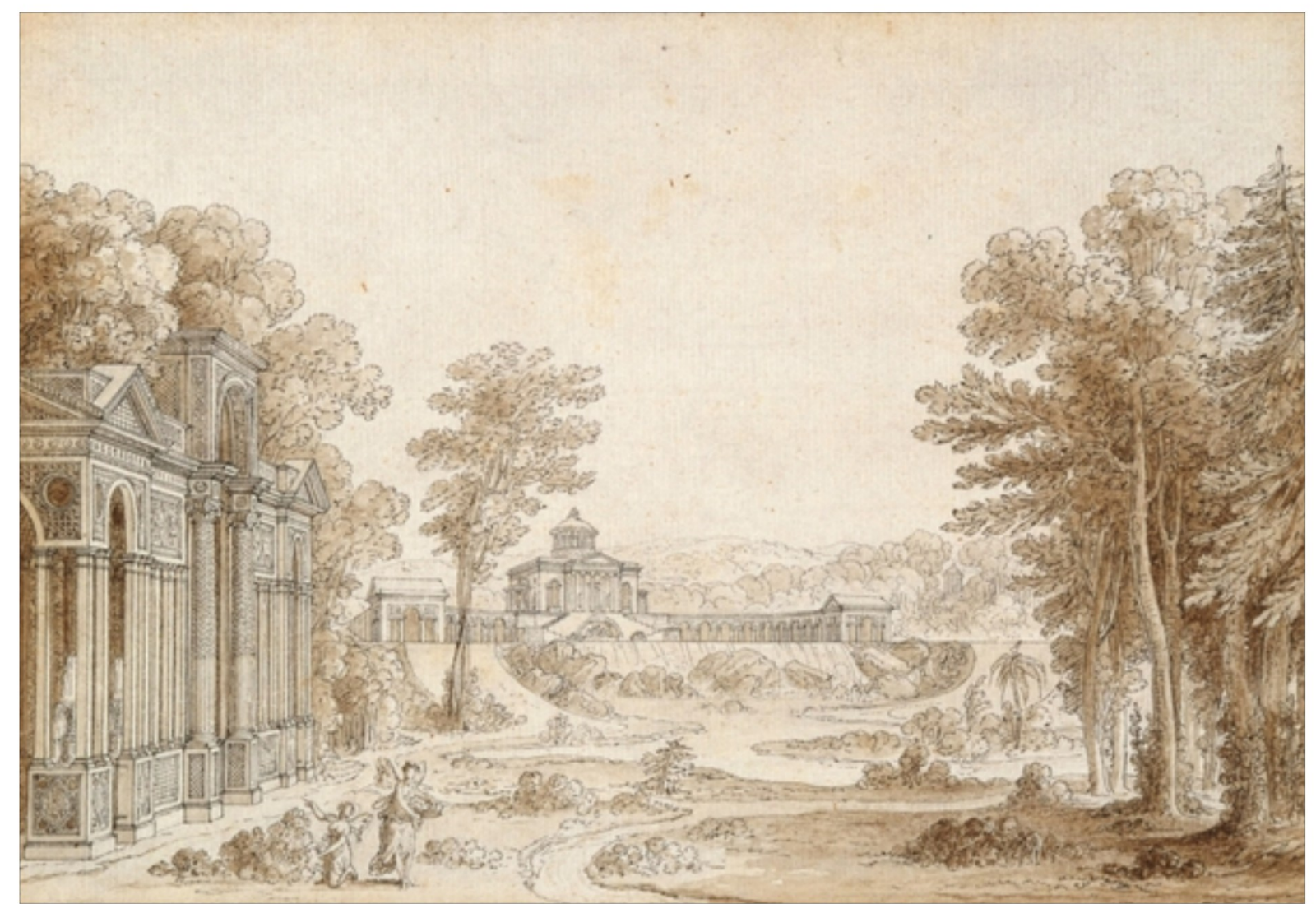

Рис. 2. Ж.Ф. Беланже (1745-1818). Дворец Флоры. Бумага, перо черным, кисть коричневым. 
Тщательно, с размерами и техникой (почти исключительный случай!), описаны семь большеформатных рисунков француза Ж.Л. Депре (1743-1804) с изображениями романтических руин древнеримских храмов, скопированы все подробные описания (или названия) на французском языке. Все листы были реквизированы в 1930 г. для Конторы Антиквариата ${ }^{28}$. Подробность инвентарных сведений (см. Приложение) дает нам надежду найти их следы. Не имеющий никаких надписей рисунок, обозначенный как «Эскиз театрального занавеса» ${ }^{29}$, изображает аллегорическую сцену с персонажами римской мифологии. Он отнесен к Депре на основании стилистических особенностей и фактов биографии мастера (историческая справка о нем предваряет сведения о блоке из семи рисунков). Рисунок выполнен, предположительно, для театра в Стокгольме, где художник провел последние 20 лет своей жизни.

Все работы Депре находились в постоянной экспозиции, их оценку дает Д.В. Прокопьев, хранитель Радищевского музея в 1921-1924 гг.: «Следует выделить восемь акварелей Л.Ж. Депре. Этот художник был некогда соперником Фрагонару, но ныне полузабыт. Его выдающиеся по мастерству рисунка и остроумию фигурных сцен архитектурные пейзажи и фантазии справедливо должны быть выдвинуты на видное место. Работы эти иллюстрируют начавшееся в 1750-е увлечение антиками, достигшее ко времени создания этих листов (1776-1784) большой популярности, что прекрасно и запечатлено художником» ${ }^{30}$. Добавим, что в 1778 г. Депре совершает учебную поездку по южной Италии, где делает многочисленные эскизы античных и средневековых построек, тогда, скорее всего, и были исполнены эти рисунки. Они тематически и стилистически составляли единый блок, которому не соответствовал более поздний «Эскиз театрального занавеса», видимо, именно поэтому не включенный в список для Конторы Антиквариата. Однако у нас нет оснований сомневаться в авторстве Ж.Л. Депре.

Два парных рисунка (третий, под этим же номером, утрачен до 1921 г.) ${ }^{31}$ также на античные темы, в инвентаре обоснованно приписаны знаменитому итальянскому театральному декоратору Пьетро Гонзага (1751-1831). Они относятся к распространенному у этого мастера типу свободных архитектурных фантазий, связанных с поисками декорационных решений, выполнены в стиле его ранних венецианских рисунков.

Представление о тематическом спектре коллекции дополняют две несохранившиеся работы, обозначенные в кокуевской описи, без размеров и техники, как «Апостол Петр» и «Жанна д’Арк» итальянской школы (в инвентарь не внесены).

Из русских живописных работ сохранилось всего две, их атрибуция, как и атрибуция занесенных в инвентарь рисунков, осталась неизменной.

«Портрет Петра I» выполнен неизвестным мастером XVIII в., как уточнено исследователями, по образцу самого известного прижизненного портрета императора, т.н. типу К. Моора - А. Матвеева ${ }^{32}$.

Особого внимания заслуживает пейзаж «Волга у Саратова» (1877) кисти М.И. ДоливоДобровольского (1841-1881) $)^{33}$ (рис. 3). Талантливый пейзажист, он, наряду с И.Е. Репиным, В.Д. Поленовым, К.А. Савицким и другими молодыми художниками в 1873-1874 гг. входил в круг пенсионеров Императорской Академии художеств в Париже, неофициальным руководителем которых был основатель Радищевского музея А.П. Боголюбов. В 1874 г. ДоливоДобровольский принимал участие в поездке в Нормандию, где под его руководством осваивал приемы пленэрной живописи. В 1877 г., видимо, также благодаря знакомству с Бого-

\footnotetext{
${ }^{28}$ СГХМ. ОХАМ Ф. «БРУ и СРМ» В.А. Оп. 5. Ед. хр. 23. Л. 1-2 (Акт от 15.03.1930 о передаче вещей, имеющих экспортное значение). Блок из семи рисунков оценен в 2000 руб. (ст. инв. № 6342-6348).

${ }^{29}$ Депре Ж.Л. Эскиз театрального занавеса. Бумага, перо красным тоном, акварель. 37,4 × 50. Инв. № Г-920 (ст. инв. № 6359).

${ }^{30}$ Прокопьев Д. Радищевский музей в Саратове: краткий обзор. Саратов, 1924. 24 с. Зал XVIII (номера стр. в издании не проставлены, только номера залов).

${ }^{31}$ Гонзага П. Архитектурный мотив. Бумага, перо, сепия. Д. 115. Инв. № Г-2865, Г-2866.

${ }^{32}$ Неизвестный художник XVIII в. Россия. Портрет Петра І. Холст, масло. 67,5 × 57,8. Инв. № Ж-601.

${ }^{33}$ Доливо-Добровольский М.И. Волга у Саратова. 1877. Холст, масло. $81 \times 128$. Инв. № Ж-182.
} 
любовым, оказался в Саратове, где провел последние четыре года своей короткой жизни. Работы художника, поэтичные и при этом передающие характерные приметы места, пользовались у саратовцев популярностью ${ }^{34}$.

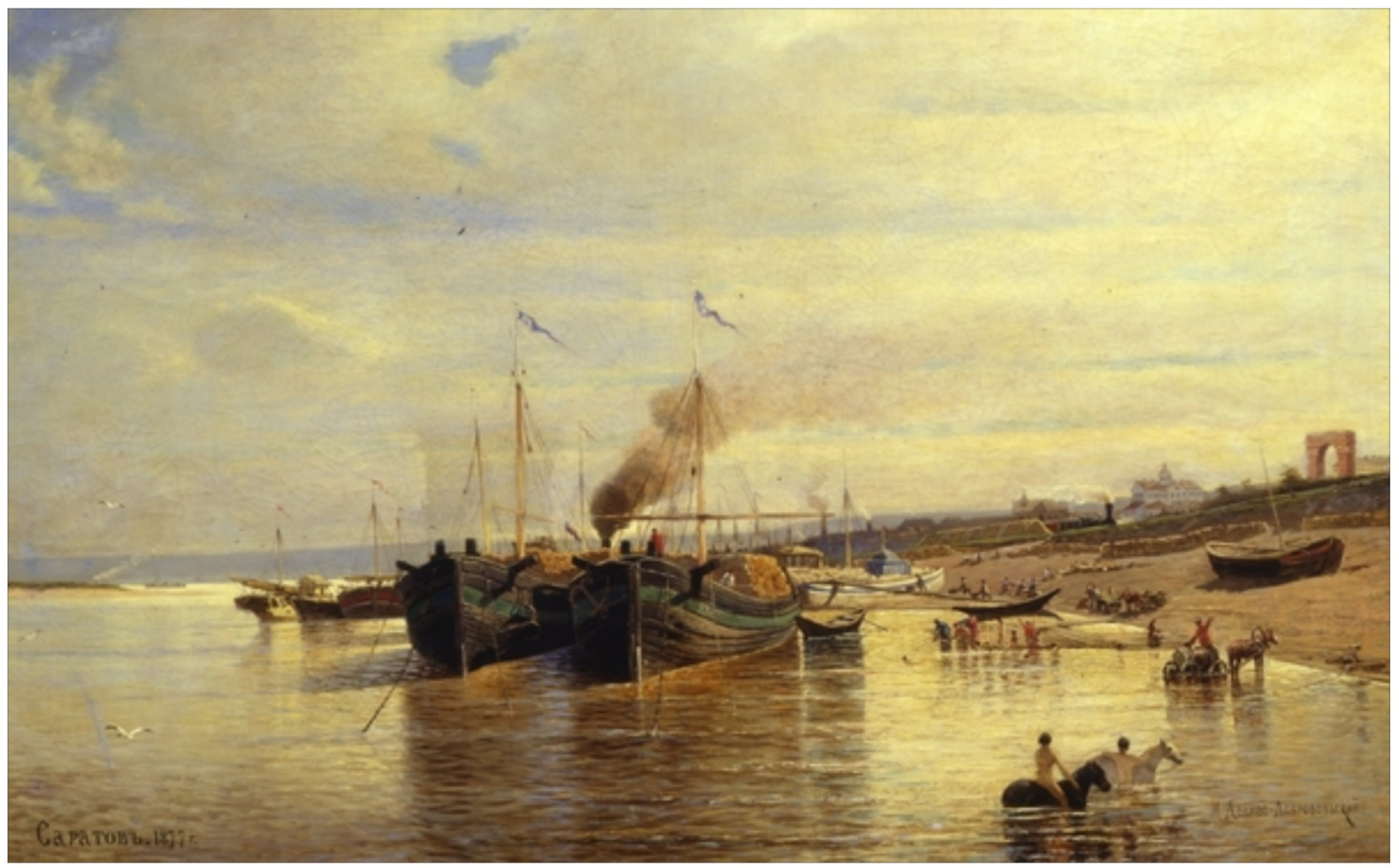

Рис. 3. М.И. Доливо-Добровольский (1841-1881). Волга у Саратова. 1877. Холст, масло.

От Кокуевых поступило три картины Доливо-Добровольского, данная, судя по изображению, значилась как «Караван баржей на Волге близ Красн[ых] ворот» ${ }^{35}$. Это название кажется более точным, чем принятое сейчас, лишенное конкретных примет, - «Волга у Саратова. 1877». На берегу, левее Триумфальной арки (выстроенной в 1869 г. для встречи царской семьи, и называемой Царскими или Красными воротами) ${ }^{36}$ виден знаменитый дом Кокуевых на Большой Сергиевской, который узнается по характерной башенке на крыше. Эти детали (дом, Царские ворота, напоминающие о роли купеческого семейства в приеме венценосной семьи, груженые товаром баржи) показывают, что картина, по всей видимости, была заказана П.И. Кокуевым. Для сравнения приведем пейзаж с таким же названием («Волга у Саратова. 1879») ${ }^{37}$, поступивший по завещанию саратовского губернатора М.И. Галкина-Враского ${ }^{38}$ и написанный в год его отъезда из Саратова (1879 г.). Но если губернатор увозил с собой на память панорамный вид со стороны Волги, то на кокуевской картине изображен пейзаж, детали которого связаны непосредственно с жизнью заказчика. Примечательно, что эта столь важная для владельцев картина внесена в инвентарь не одновременно с другими работами кокуевского списка (№ 6303-6379), а несколько позже (№ 6610), как поступление от ИЗО Губотнароба (губернского отдела народного образования). Видимо, она была передана туда сразу же после поступления из дома Кокуевых, но документов о передаче не обнаружено.

Среди русских рисунков также есть, по крайней мере, одна акварель М.И. ДоливоДобровольского - «Тройка» ${ }^{39}$, которая была выполнена, судя по авторской надписи, в Саратове в 1878 г. Скорее всего, она тоже заказана П.И. Кокуевым, возможно, в дополнение к

\footnotetext{
${ }^{34}$ Савельева Е.К. Михаил Доливо-Добровольский // Антиквариат. Предметы искусства и коллекционирования. 2008. Июль - август. С. 32-35.

${ }^{35}$ СГХМ. ОХАМ. Ф. «БРУ и СРМ». В.А. Оп. 2. Ед. хр. З. Л. 12.

${ }^{36}$ Славин И.Я. Минувшее-пережитое... С. 127.

${ }^{37}$ Доливо-Добровольский М.И. Волга у Саратова. 1879. Холст, масло. $71 \times 107$. Инв. № Ж-898.

${ }^{38}$ Га́лкин-Враской Михаил Николаевич (1832-1916), саратовский губернатор в 1870-1879 гг.
} 
уже имеющимся: из дома Кокуевых поступило четыре акварели с изображением «русских троек», символизирующих безудержный порыв русской души. Две замечательные акварели П.П. Соколова (1821-1899) ${ }^{40}$ сохранились (рис. 4); «Тройка мчит» [Н.Е] Сверчкова (1817$1898)$ - утрачена. K «Тройкам» примыкает акварельный пейзаж саратовского художника Д.Н. Россова (1835(?)-1888) с изображением повозок на берегу Волги (1865 г., в кокуевском списке 1918 г. обозначен как «Гроза») $)^{41}$.

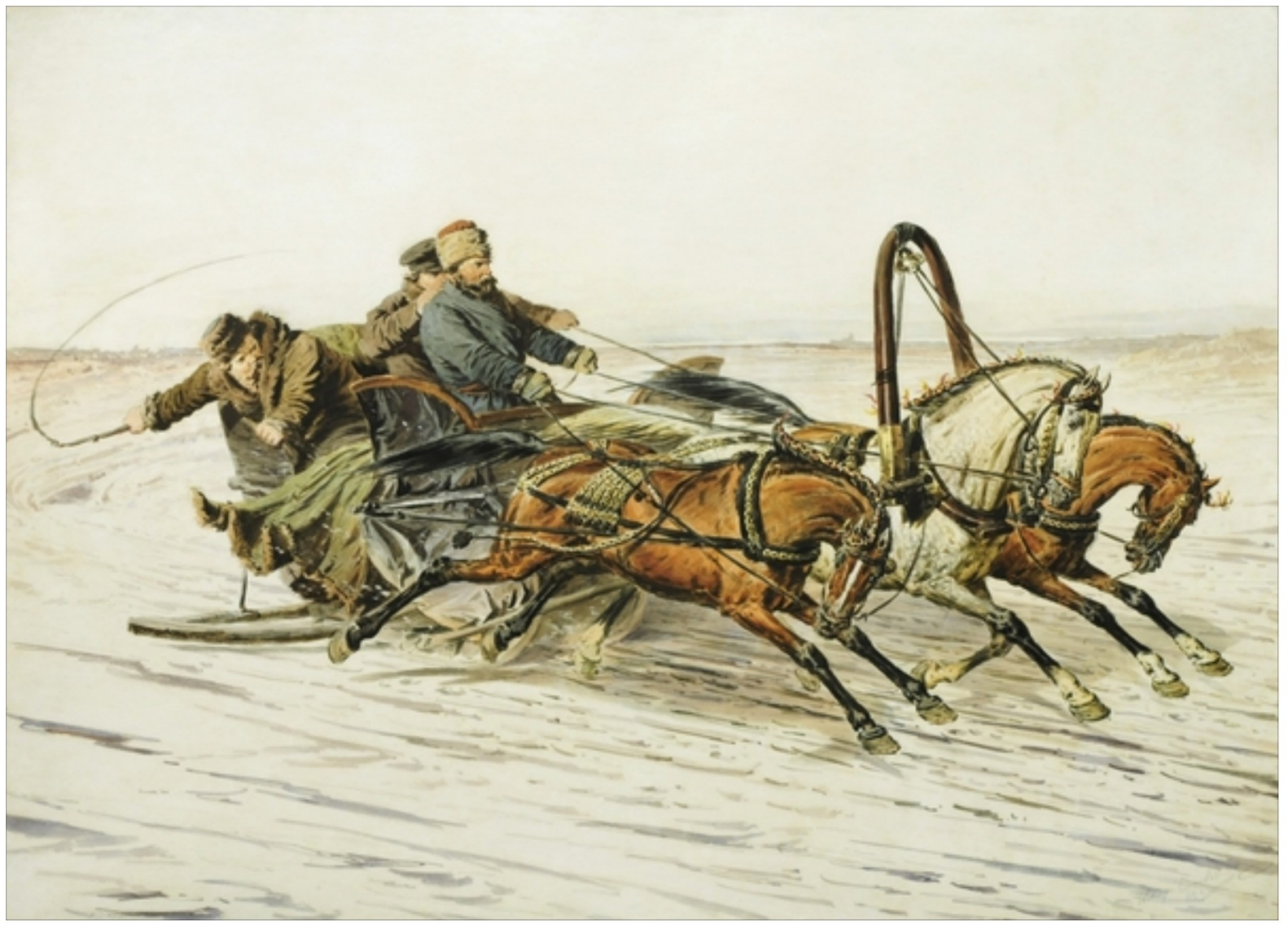

Рис. 4. П.П. Соколов (1821-1899). Тройка. Бумага, акварель.

Акварельный портрет А.В. Суворова неизвестного художника XIX в. ${ }^{42}$ (рис. 5) поступал в музей дважды: второй раз, согласно инвентарю, в 1921 г. из Историко-археологического музея ${ }^{43}$, однако, как и в большинстве других случаев обмена экспонатами, документально зафиксированного подтверждения факта выдачи не обнаружено.

Неизвестны материал и техника двух утраченных семейных портретов: портрет П.И. Кокуева в инвентаре отсутствует; второй, обозначенный в списке как «Портрет фамильный старый», в инвентаре как «Портрет неизвестного с двумя мальчиками» (№ 6378, возможно, Павла Ивановича с сыновьями), передан в 1922 г. в Музей Саратовского университета ${ }^{44}$.

\footnotetext{
${ }^{39}$ Доливо-Добровольский М.И. Тройка. Саратов. 1878. Бумага. Акварель, белила, лак, карандаш графитный. 30,2 × 37,5. Инв. № Г-3064 (ст. инв. № 6350).

${ }^{40}$ Соколов П.П. Тройка. Бумага, акварель. $65 \times 90$. Инв. № Г-3917. (ст. инв. № 6361). Тройка. Бумага, акварель. $69 \times 97$. Инв. № Г-3918 (ст. № 6362).

${ }^{41}$ Россов Д.Н. Пейзаж. 1865. Картон, акварель, лак. 28 × 36,5. Инв. № Г-3040 (ст. инв. № 6349).

${ }^{42}$ Неизвестный художник ХІХ в. Россия. Портрет А.В. Суворова. Бумага, акварель. $22 \times 27$. Инв. № Г-4866 (ст. инв. № 6351).

${ }^{43}$ Открыт в 1886 г. при создании СУАК, сейчас - Саратовский областной музей краеведения.

${ }^{44}$ Подробно о взаимопередачах см.: Приклонская В. Радищевский музей и Музей Изящных искусств Саратовского университета. K истории взаимоотношений [Электронный ресурс]. URL: http://radmuseumart.ru/projects/ articles/FineArts/ (дата обращения: 11.12.2020).
} 


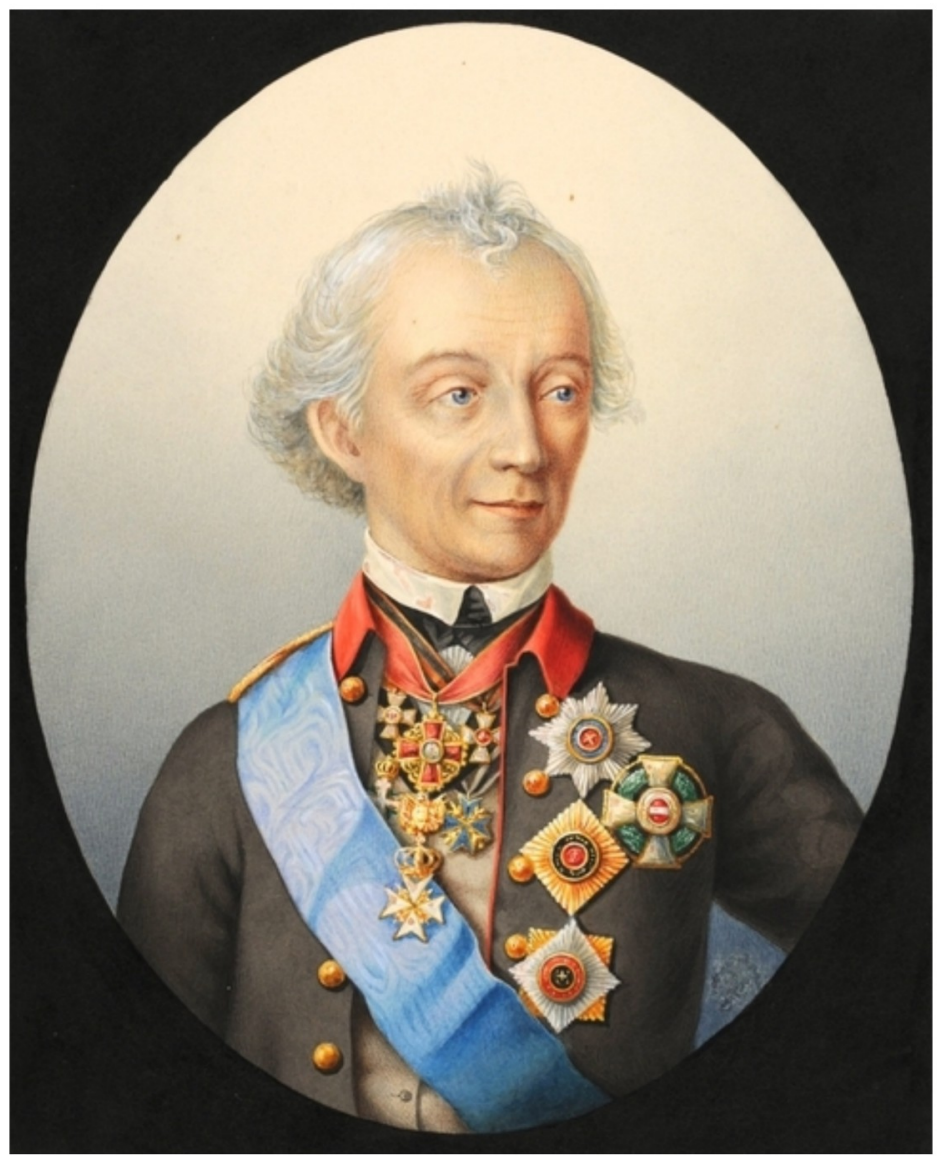

Puc. 5. Неизвестный художник XIX в. Россия.

Портрет А.В. Суворова. Бумага, акварель.

Все остальные записанные в инвентарь картины - пейзажи XIX в. Из двух работ [B.Е.] Раева (1807-1870) «Пейзаж с купальщицами» (№ 6357) передан в Вольский музей, судьба второго (№ 6358) неизвестна; «Летний пейзаж» (№ 6379) Юлия [Ю.Ю.] Клевера (1850-1924), согласно инвентарю, в 1924 г. - в ДРП (Дом работников просвещения) ${ }^{45}$.

Идентификация не внесенных в инвентарь работ вызывает особую сложность. Среди них чрезвычайную значимость имеют произведения Г.П. Баракки (1852-1915). Гектор Павлович Баракки, итальянец по происхождению, занесенный волею судьбы в Саратов - яркий и очень значимый персонаж культурной жизни Саратова. Он - один из организаторов Общества любителей изящных искусств, художник и педагог, учитель В.Э. Борисова-Мусатова. Видимо, знакомство Н.П. Кокуева и Г.П. Баракки произошло во время их совместной деятельности в ОЛИИ.

В кокуевском списке - пять работ Г.П. Баракки, все они, кроме «Волжского вида», написаны в имении Кокуевых Нижняя Чернавка ${ }^{46}$ : «Часть парка и купальня в Чернавке» (1892 г.), «Цветник и аллея в Чернавке» (1892 г.), «Пашня» (1893 г.), «Липовая аллея в Чернавке» (1893 г.). Прослеживаются сведения только об одной работе: согласно выписке из протокола № 9 от 25.10.1927 г. заседания Правления Саратовского Государственного Областного музея ${ }^{47}$ картина Баракки «Пашня» была в числе выданных из Радищевского

\footnotetext{
${ }^{45}$ Дом работников просвещения был открыт в Саратове в октябре 1924 г., в бывшем доме-дворце мукомола Шмидта, ул. Радищева, 1.

${ }^{46}$ Имение Кокуевых Нижняя Чернавка находилось в 25 верстах к северо-западу от Вольска. Здесь имелись обширные земельные угодья, с большими посевами подсолнечника, маслобойным и винокуренным заводами: Козловский И. Нижняя Чернавка // Большая Саратовская энциклопедия [Электронный ресурс]. URL: http://saratovregion.ucoz.ru/region/volskiy/n_chernavka.htm (дата обращения: 12.01.2021)

${ }^{47}$ В ноябре 1921 г. музеи города объединились в административном отношении в одно целое: Областной Саратовский музей с отделами этнографии, археологии, истории, Радищевским музеем и домом-музеем Н.Г. Чернышевского.
} 
музея во временное пользование в Дом Рабпрос (Дом работников просвещения). Работа Баракки была помечена как не вернувшаяся ${ }^{48}$.

Эта информация дает возможность понять, что, во-первых, речь идет о живописных работах Баракки (в списке техника не обозначена), во-вторых, что, по крайней мере одна из них находилась в музее вплоть до 1927 г. То обстоятельство, что они обозначены в списке с названием, именем художника и датой (обычно повторяющих надписи на работе), оставляет надежду найти эти произведения.

Правильность имен авторов некоторых картин, также не включенных в инвентарь, вызывает серьезные сомнения. Так, пейзаж «Озеро в Сев[ерной] Ит[алии])» обозначен как работа А.П. Кокуева, возможно, с ошибкой в инициале ${ }^{49}$. Пейзаж «Штиль», вероятно, ошибочно, записан как работа [Н.П.] Богданова-Бельского (1868-1945). Этот художник известен как мастер жанровых сцен но, если допустить, что в записи нет ошибки, речь идет о редком в его творчестве пейзаже. Приобретена эта картина была, видимо, Н.П. Кокуевым.

Из скульптурных произведений выделим упомянутую М.И. Кокуевой в заявлении «Амазонку» ${ }^{50}$ Е.А. Лансере, находящуюся уже много десятилетий в экспозиции музея. Из пометки в инвентаре известно, что она передавалась в историко-революционный отдел [областного музея], но документов о выдаче и возврате не обнаружено ${ }^{51}$.

Числятся предметами декоративно-прикладного искусства, но по материалу и технике исполнения являются произведениями скульптуры две парные напольные итальянские вазы из алебастра (в инвентаре - сердоликовые, № 6328), предположительно рубежа XVII-XVIII вв. ${ }^{52}$ (рис. 6). Основание вазы - в виде классической колонны с вертикальными выемками-каннелюрами, венчает ее изображение птиц, похожих на лебедей, образ которых в античной традиции ассоциировался с покровителем искусств Аполлоном. В целом конструкция вазы, ее пропорции вызывают ощущение классической гармонии и соразмерности, демонстрируя хороший вкус бывших владельцев.

Также в инвентаре записано несколько медальонов, из которых сохранился только один, с изображением Витторио Эммануэле II (Vittorio Emanuele II, 1820-1878) - первого короля единой Италии, оставшегося в истории великим борцом за объединение страны. Поступивший с ним в

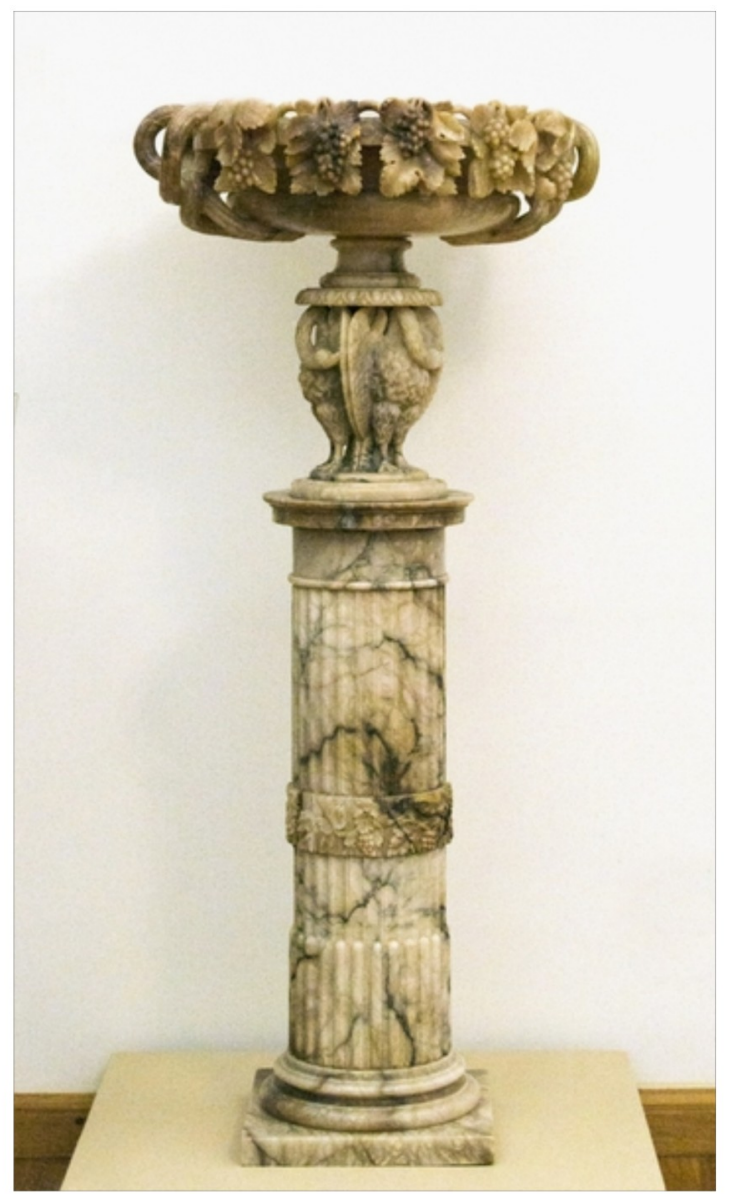

Рис. 6. Ваза напольная. Италия. Рубеж XVII-XVIII вв. Алебастр, резьба.

\footnotetext{
48 Данный документ (копия выписки) был передан из отдела учета музейных предметов Радищевского музея в ОХАМ среди старых разрозненных листов из разных дел, поэтому сделать более точную ссылку не представляется возможным (сведения получены от зав. ОХАМ И.А. Жуковой)

49 У Павла Ивановича, кроме Николая, был еще старший сын Владимир, умерший в молодости, и две дочери Надежда и Евгения (в замужестве Тиблен). Возможно, это работа кого-то из дальних родственников семьи.

50 Лансере Е.А. (1848-1886). Амазонка. 1885. Бронза, литье, патинирование. $43 \times 47$ × 24. Инв. № СК-138.

51 То, что вещи, выданные из музея, возвращались, показывает следующий документ: СГХМ. ОХАМ. Фонд «БРУ и СРМ». В.А. Оп. 5. Ед. хр. 3. Л. 21, 22, 22об.: Вещи и картины, вынесенные из музея. Копия (без даты). В нем упоминается несколько предметов из кокуевской коллекции.

52 Две декоративные вазы (парные). Италия. Рубеж XVII-XVIII вв. Алебастр, резьба. Инв. № П-2263; П-2264 (разбита).
} 
паре медальон другого национального героя Италии, Гарибальди, утрачен, также как и бюст Наполеона Бонапарта.

Вопрос о судьбе великолепной кокуевской библиотеки и собрания гравюр (поступивших в папках-альбомах ${ }^{53}$ ) остается за рамками нашего исследования. Отметим лишь, что в «Инвентарную опись изданий, принадлежащих библиотеке Государственного Радищевского музея (III)» помимо названных в начале журналов, записаны роскошные книги на русском и иностранных языках - альбомы музеев и отдельных художников, иллюстрированные художественные издания (в т.ч. издание сочиненений Дж. Г. Байрона 1856 г.) ${ }^{54}$.

Подведем итоги. Очевидно, что большинство работ кокуевского списка, не внесенных в инвентарь и обозначенных в списках передачи суммарно и условно, вряд ли возможно идентифицировать. Можно лишь предположить, куда они были переданы или с какой целью отложены в запасник. Так, «морской бой очень большой», «картины Италии очень большие, картины фламандской живописи», видимо, не прошли у А.И. Кравченко проверку «на качество», возможно, это были копии или подражания. Они могли предназначаться как для музея при университете, так и, вместе с коврами, терракотой и другими образцами ДПИ для художественно-промышленного музея. Собрание минералов, скорее всего, было отдано, вместе с дореволюционной музейной коллекцией, на кафедру геологии и минералогии университета. Работы Г. Баракки соответствовали предполагаемому музею им. В.Э. Борисова-Мусатова и хронологически (1890-е гг.), и как произведения первого учителя этого великого мастера. Однако музей открыт не был; их нет и в собрании областного краеведческого музея, куда они могли бы подойти по тематике.

Поиск утраченных кокуевских предметов затрудняет отсутствие на них инвентарных номеров и других владельческих пометок (в отличие, например, от одновременно поступивших в музей предметов коллекции П.А. Васильчикова). Вопросов пока больше чем ответов, однако мы надеемся, что приведенные нами сведения будут способствовать дальнейшим изысканиям.

Все предметы, поступившие от Кокуевых, можно условно разделить на три основные части. Самая большая - изделия ДПИ и мелкой пластики. Все они имеют художественную ценность, однако это, скорее, просто предметы быта, в которых ощутим «женский вкус» хозяйки дома (примечательно, что в ее заявлении о проверке имущества картины, рисунки, гравюры обозначены буквально одной фразой, тогда как некоторые предметы ДПИ перечисляются поштучно).

Вторая часть - произведения, непосредственно связанные с жизнью семьи: пейзажи с изображением памятных для Кокуевых мест - работы М.И. Доливо-Добровольского, Г.П. Баракки, семейные портреты неизвестных мастеров. Это, скорее, тоже не предметы собирательства, а часть семейной хроники.

Собственно, «коллекцией Кокуевых», видимо, следует назвать те предметы, которые показывают их художественные пристрастия. Прежде всего, очевидно их увлечение искусством романтизма. Подтверждением этому являются и романтические европейские пейзажи XVIII - начала XIX в., и целая подборка «русских троек» - символов русской свободной, безудержной натуры, и предметы с изображением исторических личностей, сыгравших поворотную роль в судьбах своего народа - Петра Великого, А.В. Суворова, Жанны д’Арк, Наполеона, Гарибальди, Витторио Эммануэле. Этот ряд органично дополняет собрание сочинений самого великого романтика - лорда Байрона. Классическое наследие античности тоже воспринималось ими сквозь призму романтизма - архитектурные «антики» Ж.Л. Депре и П. Гонзага, итальянские вазы XVIII в.

Очевидно, что у провинциальных купцов, даже образованных и располагающих достаточными средствами, не было таких возможностей коллекционирования, как у столичных

\footnotetext{
53 Так, под № 2031б/ф (большой формат) в музейной библиотеке записана “Architektonischen Skizzenbuch” папка со 166 гравированными архитектурными видами (1852-1886, издательство Ernst \& Korn в Берлине).

${ }^{54}$ Книги из библиотеки П.И. и Н.П. Кокуевых (с владельческими штампами обоих, некоторые - без штампов) находятся также в научной библиотеке СГУ им. Н.Г. Чернышевского.
} 
жителей. Кроме того, Кокуевы, занятые, прежде всего коммерческими делами и общественной деятельностью, вряд ли были захвачены страстью собирательства. Произведения искусства приобретались ими, скорее, как часть интерьера, как предметы, украшающие их повседневный быт. Примечательно, что среди «кокуевских» вещей нет ни одной подделки ${ }^{55}$ - обычного явления для большинства коллекций того времени. Кокуевы не гнались за именами, не старались за огромные деньги приобрести работы «старой» школы. Покупая произведения искусства, они руководствовались своим личным вкусом и, не в последнюю очередь, разумным соответствием цены и качества. Кокуевское собрание является показателем того, что не только в столице, но и в провинции во второй половине конце XIX столетия образуется новый слой русского общества - заботящееся не только о собственной прибыли, но и об общественном благоустройстве, интересующееся художествами, просвещенное купечество.

\section{Лumepamypa}

Ермолаев В.А. Без гнева и пристрастия. Записки историка / подгот. В.Н. Парфёнов, В.А. Соломонов и Т.В. Широкова. Саратов: Изд-во Саратов. ун-та, 2009. 564 с.

Козловский И. Нижняя Чернавка // Большая Саратовская энциклопедия [Электронный ресурс]. URL: http://saratovregion.ucoz.ru/region/volskiy/n_chernavka.htm (дата обращения: 12.01.2021).

Приклонская В. Радищевский музей и Музей Изящных искусств Саратовского университета. K истории взаимоотношений [Электронный ресурс]. URL: http://radmuseumart.ru/ projects/articles/FineArts/ (дата обращения: 11.12.2020).

Прокопьев Д. Радищевский музей в Саратове: краткий обзор / сост. и издал Д. Прокопьев. Саратов, 1924. 24 с.

Савельева Е.К. Михаил Доливо-Добровольский // Антиквариат. Предметы искусства и коллекционирования. 2008. Июль - август. С. 32-35.

Савельева Е.К. Общество любителей изящных искусств в Саратове. Конец XIX - начало XX века // Материалы VI Боголюбовских чтений. Художественные коллекции музеев и традиции собирательства [Электронный ресурс]. URL: http://ogis.sgu.ru/ogis/bogo/mat6/mat65.html (дата обращения 11.10.2020).

Савельева Е.К. Радищевский музей. 1918-1940 // Саратовский Радищевский музей. Факты. События. Люди. 1885-2015. Саратов: СГХМ им. А.Н. Радищева, 2016. С. 103-157.

Сайт Аукционный Дом Гелос - Gelos [Электронный ресурс]. URL: http://www.gelos.ru/ 2010/week/29.01/ (дата обращения: 15.12.2011).

Саратовский государственный художественный музей имени А.Н. Радищева. Каталог. М., 2004. Т. 1. Русская живопись XVIII-XIX вв. 560 с.

Саратовский государственный художественный музей имени А.Н. Радищева. Каталог. Саратов, 2008. Т. 2. Зарубежное искусство. Живопись, рисунок, скульптура, шпалеры: каталог. 504 с.

Семенов В.Н., Семенов Н.Н. Саратов купеческий. Саратов: Изд-во журнала «Волга», 1995. 352 c.

Славин И.Я. Минувшее-пережитое. Воспоминания. Саратов: КнигоГрад, 2013. 404 с.

Соколов В.П. 25-летие Саратовской ученой архивной комиссии [Электронный ресурс]. URL: http://annales.info/rus/small/suak25.htm (дата обращения: 11.10.2020).

Соломонов В., Чернышов А. Цель - университет // Годы и люди. Саратов: Приволж. кн. изд-во, 1988. Вып. 3. С. 216-231.

Хроника художественной жизни Саратова 1874-1980. По материалам периодической печати. Саратов: Изд-во Саратов. ун-та, 1988. 116 с.

\footnotetext{
${ }^{55}$ На картинах, не включенных в инвентарь, нет фальшивых подписей - обозначенное имя было бы наверняка, как во всех остальных случаях, зафиксировано в списках передачи.
} 


\section{References}

Ermolaev, V.A. (2009). Bez gneva i pristrastiya. Zapiski istorika [Without anger and addiction. The historian's notes]. Saratov, Izd-vo Saratovskogo un-ta. 564 p.

(1988). Khronika khudozhestvennoy zhizni Saratova 1874-1980. Po materialam periodicheskoy pechati. [Chronicle of the artistic life of Saratov in 1874-1980. Based on the materials of the periodical press]. Saratov, Izdatel'stvo Saratovskogo universiteta. 116 p.

Kozlovskiy, I. Nizhnyaya Chernavka [Nizhnyaya Chernavka]. In Bol'shaya Saratovskaya entsiklopediya [Elektronnyy resurs]. Available at: URL: http://saratovregion.ucoz.ru/region/ volskiy/n_chernavka.htm (date of access 12.01.2020).

Priklonskaya, V. Radishchevskiy muzey i Muzey Izyashchnykh iskusstv Saratovskogo universiteta. $K$ istorii vzaimootnosheniy [The Radishchev Museum and The Museum of Fine Arts of the Saratov University. To the history of relationships]. Available at: URL:http://radmuseumart.ru/ projects/articles/FineArts/ (date of access 11.12.2020).

Prokop’ev, D. (1924). Radishchevskiy muzey v Saratove: kratkiy obzor [Radishchevskiy muzey in Saratov: short overview]. Saratov. 24 p.

(2004). Saratovskiy gosudarstvennyy khudozhestvennyy muzey imeni A.N. Radishcheva. Katalog. T. 1. Russkaya zhivopis' XVIII-XIX vv. [Saratov State Radischev Art Museum: catalog. Vol. 1. Russian paintings of the $18^{\text {th }}-19^{\text {th }}$ centuries]. Moscow. 560 p.

(2008). Saratovskiy gosudarstvennyy khudozhestvennyy muzey imeni A.N. Radishcheva. Katalog. T. 2. Zarubezhnoe iskusstvo. Zhivopis', risunok, skul'ptura, shpalery [Saratov State Radischev Art Museum: catalog. Vol. 2. Foreign art. Painting, drawing, sculpture, tapestries]. Saratov. 504 p.

Savel'eva, E.K. (2008). Mikhail Dolivo-Dobrovol'skiy [Mikhail Dolivo-Dobrovolsky]. In Antikvariat. Predmety iskusstva i kollektsionirovaniya. Iyul' - avgust, pp. 32-35.

Savel'eva, E.K. (2016). Radishchevskiy muzey. 1918-1940 [The Radishchev Museum. 19181940]. In Saratovskiy Radishchevskiy muzey. Fakty. Sobytiya. Lyudi. 1885-2015. Saratov, SGKHM imeni A.N. Radishcheva, pp. 103-157.

Savel'eva, E.K. Obshchestvo lyubiteley izyashchnykh iskusstv v Saratove. Konets XIX nachalo XX veka [The Society of Friends of Fine Arts in Saratov. Late $19^{\text {th }}-$ early $20^{\text {th }}$ century]. In Materialy VI Bogolyubovskikh chteniy. Khudozhestvennyye kollektsii muzeev i traditsii sobiratel'stva. Available at: URL: http://ogis.sgu.ru/ogis/bogo/mat6/mat6-5.html (date of access 11.10.2020).

Semenov, V.N., Semenov N.N. (1995). Saratov kupecheskiy [The Merchants of Saratov]. Saratov, Izd-vo zhurnala "Volga". 352 p.

Site Auktsionnogo Doma Gelos [Website of the Gelos Auction House]. Available at: URL: http://www.gelos.ru/2010/week/29.01/ (date of access 15.12.2011).

Slavin, I.Ya. (2013). Minuvsheye-perezhitoye. Vospominaniya [The past. The memories]. Saratov, KnigoGrad. 404 p.

Sokolov, V.P. 25-letie Saratovskoy uchenoy arkhivnoy komissii $\left[25^{\text {th }}\right.$ anniversary of the Saratov Scientific Archival Commission]. Available at: URL: http://annales.info/rus/small/suak25.htm (date of access 11.10.2020).

Solomonov V., Chernyshov, A. (1988). Tsel' - universitet [University is the goal]. In Gody $i$ lyudi. Saratov, Privolzh. kn. izd-vo. Iss. 3, pp. 216-231. 


\section{Предметы и картины из собрания Кокуевых, занесенные в инвентарь 1919 г.: старые и новые атрибуции}

\begin{tabular}{|c|c|c|c|}
\hline \multicolumn{2}{|c|}{$\begin{array}{l}\text { Данные по: } \\
\text { «Инвентарь Радищевского музея». } 1919 . \\
\text { Т. 2. Л. 175-183 } \\
\text { (Предметы из собрания сарат[овского] } \\
\text { дворянина Кокуева из дома на } \\
\text { Большой Сергиевской) }\end{array}$} & \multicolumn{2}{|c|}{ Современные данные } \\
\hline Инв. № & Изделие & Инв. № & Изделие \\
\hline \multicolumn{4}{|c|}{ Предметы } \\
\hline 6303 & $\begin{array}{l}\text { Зеленый стеклянный стакан с } \\
\text { прикл. вензелем }\end{array}$ & П-1364 & $\begin{array}{l}\text { Европа. Вторая половина XIX - } \\
\text { начало XX в. } \\
\text { Стакан }\end{array}$ \\
\hline 6304 & Хрустальное блюдце & П-1372 & $\begin{array}{l}\text { Неизвестный завод. } \\
\text { ХІХ в. Блюдце }\end{array}$ \\
\hline 6305 & $\begin{array}{l}\text { Зеленая бутылка } \\
\text { венецианского стекла }\end{array}$ & П-1255 & $\begin{array}{l}\text { Западная Европа (?). } \\
\text { Вторая половина XIX в. } \\
\text { Бутылка с пробкой }\end{array}$ \\
\hline 6306 & $\begin{array}{l}\text { Стеклянная голубая кружка } \\
\text { с инициалом «ПК» }\end{array}$ & П-1397 & $\begin{array}{l}\text { Россия. Императорский } \\
\text { стеклянный завод (?) XIX в. } \\
\text { Кружка }\end{array}$ \\
\hline 6307 & $\begin{array}{l}\text { Граненый стакан с белым } \\
\text { матовым стеклом }\end{array}$ & П-1380 & $\begin{array}{l}\text { Россия. XVIII-XIX вв. } \\
\text { Графин }\end{array}$ \\
\hline 6308 & $\begin{array}{l}\text { Чашки фабрики Киселева } \\
\text { (тарелки) / При проверке не } \\
\text { найдены. 15/III } 1925 \text { г. }\end{array}$ & $\begin{array}{l}\Pi-372 \\
\Pi-376\end{array}$ & $\begin{array}{l}\text { Завод Терехова и Киселевых. } \\
\text { 1832-1851 гг. Две чашки } \\
\text { (аналогичные) }\end{array}$ \\
\hline 6309 & $\begin{array}{l}\text { Кофейная чашка фабрики } \\
\text { Гарднер, белая с позолотой, в } \\
\text { форме раковины }\end{array}$ & П-398 & $\begin{array}{l}\text { Завод Гарднера. 1840-е гг. } \\
\text { Чашка }\end{array}$ \\
\hline 6310 & $\begin{array}{l}\text { Пепельница фарфоровая } \\
\text { корзинкой, фабрика Гарднер } \\
40-50-\text { х гг. XIX в. }\end{array}$ & П-418 & $\begin{array}{l}\text { Завод Гарднера 1840-1850-е гг. } \\
\text { Пепельница }\end{array}$ \\
\hline 6311 & $\begin{array}{l}\text { Чашки, блюдца и сахарница } \\
\text { венецианского фарфора } \\
\text { темно-красного с орнаментом } \\
\text { в стиле «рококо» матового } \\
\text { золота. Марка синяя: пчела и } \\
\text { под ней подпись “Venezia” }\end{array}$ & П-687 & $\begin{array}{l}\text { Венецианский завод. } \\
\text { Сервиз: чашки (7), блюдца (8) } \\
\text { и сахарница }\end{array}$ \\
\hline 6312 & $\begin{array}{l}\text { Чашка с блюдцем фабрики } \\
\text { Корнилова. Украшенная } \\
\text { орнаментом в русском стиле }\end{array}$ & П-382 & $\begin{array}{l}\text { Завод братьев Корниловых. } \\
\text { Чашка с блюдцем }\end{array}$ \\
\hline
\end{tabular}




\begin{tabular}{|c|c|c|c|}
\hline 6313 & $\begin{array}{l}\text { Чашка с блюдцем фабрики } \\
\text { “France”. Современная работа }\end{array}$ & $\begin{array}{l}\Pi-710 / 1 \\
\Pi-710 / 2\end{array}$ & $\begin{array}{l}\text { Франция, Лимож. Фабрика } \\
\text { М. Редона. Конец ХIX в. } \\
\text { Чашка с блюдцем }\end{array}$ \\
\hline 6314 & $\begin{array}{l}\text { Статуэтка фабрики Гарднер } \\
\text { «Мальчик с лейкой». Марка } \\
\text { давленая, герб «гарднеръ» } \\
\text { синяя подглазурная. Побита }\end{array}$ & П-403 & $\begin{array}{l}\text { Завод Гарднера. 1800-1820-е гг. } \\
\text { Статуэтка Мальчик с лейкой }\end{array}$ \\
\hline 6315 & $\begin{array}{l}\text { Два маленьких парных } \\
\text { подсвечника фабрики } \\
\text { Тереховых и Киселева }\end{array}$ & $\begin{array}{l}\Pi-369 / 1 \\
\Pi-369 / 2\end{array}$ & $\begin{array}{l}\text { Завод Терехова и Киселевых. } \\
\text { 1832-1851 гг. Два подсвечника }\end{array}$ \\
\hline 6316 & $\begin{array}{l}\text { Фарфоровая пепельница с } \\
\text { маркой “SR” в круге новая }\end{array}$ & П-672 & $\begin{array}{l}\text { Завод Сименса и Гальске. } 1860-е- \\
\text { начало } 1880-x \text { гг. Пепельница }\end{array}$ \\
\hline П-6317 & $\begin{array}{l}\text { Статуэтка фабрики Гарднер } \\
\text { «Дама с муфтой» } \\
\text { (обнаженная). } \\
\text { (воспроизведена в «Истории } \\
\text { Скульптуры» Врангеля. } \\
\text { А.В. и В.В. Леонтьевы }{ }^{\text {a }} \text { ) }\end{array}$ & П-345 & $\begin{array}{l}\text { Завод Гарднера. } \\
\text { Статуэтка Дама с муфтой. } \\
\text { Середина XIX в. }\end{array}$ \\
\hline 6318 & $\begin{array}{l}\text { Статуэтка фабрики Корнилова } \\
\text { «Дама с муфтой» }\end{array}$ & П-379 & $\begin{array}{l}\text { Завод братьев Корниловых. } \\
\text { Статуэтка Женщина с книгой }\end{array}$ \\
\hline 6319 & $\begin{array}{l}\text { Статуэтка фабрики Көршлева } \\
\text { «Баба», завод Гарднера } \\
\text { 60-70-е гг. XIX в. }\end{array}$ & П-401 & $\begin{array}{l}\text { Завод Гарднера. } \\
\text { Статуэтка Стоящая крестьянка. } \\
\text { 1850-1860-е гг. }\end{array}$ \\
\hline 6320 & $\begin{array}{l}\text { Чашка русская старая с синим } \\
\text { и розовым рисунком, лубок, } \\
\text { склеена. А.В. и } \\
\text { В.В. Леонтьевы }\end{array}$ & П-365 & $\begin{array}{l}\text { Завод братьев Кузнецовых. } \\
\text { Чашка. } 1840 \text { - начало 1860-х гг. }\end{array}$ \\
\hline 6321 & $\begin{array}{l}\text { Вазочка с позолотой } \\
\text { неизвестного фарфорового } \\
\text { завода, середина XIX в. }\end{array}$ & П-655 & $\begin{array}{l}\text { Россия. Гжель (?). } \\
\text { Ваза-цветок. Середина XIX в. }\end{array}$ \\
\hline 6322 & $\begin{array}{l}\text { Статуэтка фабрики } \\
\text { Корниловых. } \\
\text { Пляшущая девушка }\end{array}$ & П-367 & $\begin{array}{l}\text { Завод братьев Корниловых. } \\
\text { Статуэтка Пляшущая девушка }\end{array}$ \\
\hline 6323 & Кувшин фабрики Корниловых & П-383 & $\begin{array}{l}\text { Завод братьев Корниловых. } \\
\text { Кувшин. 1861-1884 гг. }\end{array}$ \\
\hline 6324 & $\begin{array}{l}\text { Две парные вазы } \\
\text { Императорского завода эпохи } \\
\text { Александра III синего тона с } \\
\text { золотыми рельефными } \\
\text { накладками (маски) и } \\
\text { росписью в псевдо- } \\
\text { ренессансном стиле }\end{array}$ & $\begin{array}{l}\Pi-851 / 1 \\
\Pi-851 / 1\end{array}$ & $\begin{array}{l}\text { Императорский фарфоровый } \\
\text { завод. Две парные вазы. 1860-е гг. }\end{array}$ \\
\hline
\end{tabular}

а.В. и В.В. Леоньтьевы - известные саратовские краеведы и фотографы, в 1930-е гг. сотрудники СГХМ. 


\begin{tabular}{|c|c|c|c|}
\hline 6325 & $\begin{array}{l}\text { Ваза зеленая фарфоровая } \\
\text { неизвестной русской (?) } \\
\text { фабрики середины XIX в. (?). } \\
\text { На лицевой стороне медальон } \\
\text { с букетом цветов на белом } \\
\text { фоне }\end{array}$ & П-462 & $\begin{array}{l}\text { Императорский фарфоровый } \\
\text { завод (?). Ваза. Середина XIX в. - } \\
\text { 1870-е гг. }\end{array}$ \\
\hline 6326 & $\begin{array}{l}\text { Китайская ваза с гротескным } \\
\text { рисунком. Плоская на } \\
\text { тройных ножках с маркой из } \\
\text { трех букв }\end{array}$ & П-860 & $\begin{array}{l}\text { Япония, Иокогама } \\
\text { Конец XIX в. Ваза }\end{array}$ \\
\hline 6327 & $\begin{array}{l}\text { Черные деревянные точеные } \\
\text { вазы (кратеры) с } \\
\text { барельефными поясками из } \\
\text { изображений бабочек, } \\
\text { женщин, склонившихся над } \\
\text { урнами, ивами и пр. }\end{array}$ & $\begin{array}{l}\Pi-1176 / 1 \\
П-1176 / 2\end{array}$ & $\begin{array}{l}\text { Первая треть ХІХ в. Россия. } \\
\text { И.Ю. Цейзик (1779-1858). } \\
\text { Вазы парные }\end{array}$ \\
\hline 6328 & $\begin{array}{l}\text { Две белые сердоликовые вазы } \\
\text { итальянской работы (?) первой } \\
\text { половины ХІХ в. с } \\
\text { барельефными } \\
\text { изображениями. Одна ваза с } \\
\text { разбитым основанием }\end{array}$ & $\begin{array}{l}\Pi-2263 \\
\Pi-2264\end{array}$ & $\begin{array}{l}\text { Две вазы. Италия. Рубеж XVII- } \\
\text { XVIII вв. Алебастр, резьба }\end{array}$ \\
\hline 6329 & $\begin{array}{l}\text { Чашки с блюдцами кофейные, } \\
\text { фабрики Гарднера, середина } \\
\text { XIX в. (6 чашек, } 8 \text { блюдец) }\end{array}$ & $\begin{array}{l}\Pi-412 / 1- \\
\Pi-412 / 14\end{array}$ & $\begin{array}{l}\text { Завод Гарднера.1840-е гг. } \\
\text { Чашки с блюдцами (14 } \\
\text { предметов) }\end{array}$ \\
\hline 6330 & $\begin{array}{l}\text { Стол письменный } \\
\text { французский, XVII в. Эпохи } \\
\text { Людовика (регентства), } \\
\text { украшения из бронзы. Сукно } \\
\text { желтовато-коричневого тона, } \\
\text { окантованное полосками } \\
\text { коричневой тисненой золотом } \\
\text { кожи. Подобный стол был в } \\
\text { собрании Утемана (Старые } \\
\text { годы, 1907). Плохой } \\
\text { сохранности }\end{array}$ & - & $\begin{array}{l}\text { Передано конторе } \\
\text { «Антиквариат». Акт от } 11 \\
\text { сентября } 1920 \text { г. }\end{array}$ \\
\hline 6331 & $\begin{array}{l}\text { Два подсвечника деревянных, } \\
\text { золоченых с хрустальными } \\
\text { колонками, стиля Empire, } \\
\text { первая половина XIX в. }\end{array}$ & $\begin{array}{l}\Pi-2063 \\
\Pi-2064\end{array}$ & $\begin{array}{l}\text { Первая половина XIX в. } \\
\text { Два подсвечника }\end{array}$ \\
\hline 6332 & $\begin{array}{l}\text { «Амазонка», бронзовая } \\
\text { статуэтка работы Е. Лансере. } \\
\text { Передана в историко- } \\
\text { революционный отдел } \\
\text { областного музея }\end{array}$ & CK-138 & $\begin{array}{l}\text { Е.А. Лансере } \\
\text { Амазонка. Конная статуэтка. } \\
1885 \text { г. }\end{array}$ \\
\hline
\end{tabular}




\begin{tabular}{|c|c|c|c|}
\hline 6333 & $\begin{array}{l}\text { Флакон для духов, фарфор, } \\
\text { покрытый мелкими } \\
\text { рельефными цветами, новый }\end{array}$ & - & $\begin{array}{l}\text { Западная Европа. Флакон } \\
\text { для духов. Начало XIX в. }\end{array}$ \\
\hline 6334 & $\begin{array}{l}\text { Вазочка с персидским } \\
\text { рисунком }\end{array}$ & - & $\begin{array}{l}\text { При проверке не найдена. } \\
\text { 25/III-1925 г. }\end{array}$ \\
\hline 6335 & $\begin{array}{l}\text { Две вазочки cloisonee c } \\
\text { зеленым фоном }\end{array}$ & - & $\begin{array}{l}\text { При проверке не найдена. } \\
\text { 25/III-1925 г. }\end{array}$ \\
\hline 6336 & $\begin{array}{l}\text { Сумочка дамская новая, } \\
\text { украшенная } \\
\text { гальванопластикой }\end{array}$ & П-2374 & Сумочка кожаная \\
\hline 6337 & Серебряный гребешок & - & $\begin{array}{l}\text { При проверке не найдена. } \\
\text { 25/III-1925 г. }\end{array}$ \\
\hline 6338 & $\begin{array}{l}\text { Персидские трубки с } \\
\text { инкрустациями }\end{array}$ & - & $\begin{array}{l}\text { При проверке не найдена. } \\
\text { 25/III-1925 г. }\end{array}$ \\
\hline 6339 & $\begin{array}{l}\text { Дама с розой, статуэтка новая } \\
\text { фабрики Корниловых } \\
\text { (поломана) }\end{array}$ & П-368 & $\begin{array}{l}\text { Завод братьев Корниловых. } \\
\text { Статуэтка. Женщина с розой }\end{array}$ \\
\hline 6340 & Флакон для одеколона & П-1224 & $\begin{array}{l}\text { Графин. 1830-е гг. } \\
\text { Россия, Пензенская губерния (?). } \\
\text { Николо-Пестровский завод } \\
\text { Бахметевых }\end{array}$ \\
\hline \multicolumn{4}{|c|}{ Картины и рисунки } \\
\hline- & $\begin{array}{l}\text { Серия рисунков и акварелей } \\
\text { Lous Jean Despres (родился в } \\
\text { Лионе или Оксерре в } 1743 \text { г., } \\
\text { ученик по архитектуре } \\
\text { Блонделя и также Руэна и } \\
\text { Дэмезона получил «римскую» } \\
\text { поездку на конкурсе } 1776 \text { г. за } \\
\text { проект «Замок грансеньера». } \\
\text { Из Рима, заручившись } \\
\text { благоволением шведского } \\
\text { короля Густава ІІІ, следует за } \\
\text { ним в } 1784 \text { г. в Стокгольм, где } \\
\text { работает, сочиняя декорации } \\
\text { для оперы и исторические } \\
\text { картины. Умер там же в } 1803 \\
\text { или } 1804 \text { г. Все большие } \\
\text { картины и значительная часть } \\
\text { других его произведений } \\
\text { находятся в Швеции. В России } \\
\text { работы Деспрэ имеются в } \\
\text { Эрмитаже, Павловске, а в } \\
\text { собрании А.Н. Бенуа «Занавес } \\
\text { Стокгольмской оперы» }\end{array}$ & - & - \\
\hline
\end{tabular}




\begin{tabular}{|c|c|c|c|}
\hline 6341 & $\begin{array}{l}\text { Руины древнеримского храма } \\
\text { с молящимся монахом и } \\
\text { женщинами. Акварель с } \\
\text { пером. В.76, ш. } 55 \text { см. Парная } \\
\text { следующей }\end{array}$ & - & Переданы в антиквариат \\
\hline 6342 & $\begin{array}{l}\text { Руины древнеримского храма } \\
\text { с часовней, и гуляющим } \\
\text { путешественником. Акварель } \\
\text { с пером. В. 76, ш. } 55 \text { см. } \\
\text { Парная следующей }\end{array}$ & - & То же \\
\hline 6343 & $\begin{array}{l}\text { Grotte de Poselippe de nuite à } \\
\text { Naples [Грот Позелиппо } \\
\text { ночью]. Акварель с пером. } \\
\text { В. 70, ш. } 47 \text { см. Подпись по } \\
\text { наклейке снизу “Despres”. } \\
\text { Парная следующей }\end{array}$ & - & $»$ \\
\hline 6344 & $\begin{array}{l}\text { Illumination de la Croix de } \\
\text { St. Pierre a Rome. Акварель } \\
\text { с пером. В. 70, ш. } 47 \text { см. } \\
\text { Подпись по наклейке снизу } \\
\text { “Despres”. Парная } \\
\text { предыдущей }\end{array}$ & - & $\gg$ \\
\hline 6345 & $\begin{array}{l}\text { Внутренность древнеримского } \\
\text { храма с религиозной } \\
\text { процессией. Акварель с пером. } \\
\text { В. 45,5, ш. 63,5 см. Парная } \\
\text { следующей }\end{array}$ & - & $»$ \\
\hline 6346 & $\begin{array}{l}\text { Внутренность древнеримского } \\
\text { храма с религиозной } \\
\text { процессией. Акварель с пером. } \\
\text { В. 45,5, ш. 63,5 см. Парная } \\
\text { предыдущей }\end{array}$ & - & $»$ \\
\hline 6347 & $\begin{array}{l}\text { Vue des Ruines du temple de à } \\
\text { Junon a Metapontum dans La } \\
\text { Basilicate } \mathrm{P}^{\mathrm{ee}} \text { du } \mathrm{R}^{\mathrm{m}} \mathrm{e} \text { le Naples. } \\
\text { Акварель с пером. } \\
\text { В. 21, ш. 34,5 см. } \\
\text { Подпись по наклейке снизу } \\
\text { “Despres del”. } \\
\text { Парная следующей }\end{array}$ & - & $»$ \\
\hline 6348 & $\begin{array}{l}\text { Vue de portail de L’Eglise de } \\
\text { Sama mo Philippe... à Naples. } \\
\text { Акварель с пером. В. 21, } \\
\text { ш. 34,5 см. Подпись по } \\
\text { наклейке снизу “Despres del”. } \\
\text { Парная предыдущей }\end{array}$ & - & $»$ \\
\hline
\end{tabular}




\begin{tabular}{|c|c|c|c|}
\hline 6349 & $\begin{array}{l}\text { Россов Дмитрий Николаевич. } \\
\text { Пейзаж. Акварель. Подпись } \\
\text { процарапана в левом нижнем } \\
\text { углу «Д. Россовъ } 1865 \text { г.» }\end{array}$ & $\Gamma-3040$ & Д.Н. Россов. 1865 г. \\
\hline 6350 & $\begin{array}{l}\text { Доливо-Добровольский. } \\
\text { Тройка. Акварель с клеем. } \\
\text { Подпись }\end{array}$ & $\Gamma-3064$ & $\begin{array}{l}\text { М.И. Доливо-Добровольский. } \\
\text { Тройка. Саратов }\end{array}$ \\
\hline 6351 & $\begin{array}{l}\text { Неизвестный художник конца } \\
\text { XVIII - начала XIX в. } \\
\text { Портрет Суворова }\end{array}$ & $\Gamma-4866$ & $\begin{array}{l}\text { Неизвестный художник XIX в. } \\
\text { Суворов. Поступил в } 1921 \text { г. из } \\
\text { Историко-археологического } \\
\text { музея. Передача (повторно) }\end{array}$ \\
\hline 6352 & $\begin{array}{l}\text { Неизвестный художник } \\
\text { первой половины XIX в. } \\
\text { Декоративный пейзаж } \\
\text { (на опушке леса всадница } \\
\text { с кавалером). Масло }\end{array}$ & Ж-526 & $\begin{array}{l}\text { Германия, начало XIX в. } \\
\text { Пейзаж с всадниками }\end{array}$ \\
\hline 6353 & $\begin{array}{l}\text { Неизвестный художник } \\
\text { первой половины ХІХ в. } \\
\text { Декоративный пейзаж } \\
\text { «Рыбаки на озере». Масло }\end{array}$ & Ж-1063 & $\begin{array}{l}\text { Европа, конец XVIII в. } \\
\text { Рыбаки на озере }\end{array}$ \\
\hline 6354 & $\begin{array}{l}\text { Неизвестный художник конца } \\
\text { XVIII - начала XIX в. (?) } \\
\text { Декоративный пейзаж } \\
\text { (Озеро, на переднем плане под } \\
\text { большим деревом человек в } \\
\text { красном кафтане). Масло }\end{array}$ & Ж-627 & $\begin{array}{l}\text { Европа, конец XVIII в. - XIX в. } \\
\text { Декоративный пейзаж }\end{array}$ \\
\hline 6355 & $\begin{array}{l}\text { Неизвестный художник конца } \\
\text { XVIII - начала XIX в. (?) } \\
\text { Декоративный пейзаж } \\
\text { «Дорога в лесу с идущим } \\
\text { человеком». Масло, парная к } \\
\text { предыдущей и следующей }\end{array}$ & Ж-1011 & $\begin{array}{l}\text { Швейцария (?), конец XVIII в. } \\
\text { Горный пейзаж }\end{array}$ \\
\hline 6356 & $\begin{array}{l}\text { Неизвестный художник. } \\
\text { Декоративный пейзаж. } \\
\text { Парный к предыдущей }\end{array}$ & Ж-1010 & $\begin{array}{l}\text { Англия, начало XIX в. Коровы на } \\
\text { водопое }\end{array}$ \\
\hline 6357 & $\begin{array}{l}\text { Райев Василий Егорович. } \\
\text { 1807-1870 гг. } \\
\text { Купальщицы (пейзаж). } \\
\text { На обороте надпись «Пис. } \\
\text { В. Раевъ. } 1830 \text { (Эпохи } \\
\text { пребывания в ступинской } \\
\text { арзамасской школе)». } \\
\text { Парный следующей }\end{array}$ & - & $\begin{array}{l}\text { Помечено: передано в Вольский } \\
\text { музей }\end{array}$ \\
\hline 6358 & $\begin{array}{l}\text { Райев Василий Егорович. } \\
\text { 1807-1870 гг. } \\
\text { Пейзаж. Парный предыдущей }\end{array}$ & - & Помечено: в реставрации \\
\hline
\end{tabular}




\begin{tabular}{|c|c|c|c|}
\hline 6359 & $\begin{array}{l}\text { Приписывается Дэзпрэ. } \\
\text { (см. предварит. примеч. } \\
\text { к № 6341) Проект театрального } \\
\text { занавеса (возможно, для } \\
\text { Стокгольмской королевской } \\
\text { оперы. Акварель с пером } \\
\text { (красные чернила) } \\
\text { В. 38, ш. } 51 \text { см }\end{array}$ & $\Gamma-920$ & $\begin{array}{l}\text { Ж.Л. Депре (?) } \\
\text { Проект театрального занавеса }\end{array}$ \\
\hline 6360 & $\begin{array}{l}\text { Belanger Architecte. } \\
\text { Palais de Flore. Рисунок пером, } \\
\text { подправленный сепией, 20×28 }\end{array}$ & $\Gamma-867$ & $\begin{array}{l}\text { Ф.Ж. Беланже (1745-1818). } \\
\text { Дворец Флоры }\end{array}$ \\
\hline 6361 & $\begin{array}{l}\text { Петр Соколов. Тройка. } \\
\text { Акварель. Бумага. }\end{array}$ & Г-3917 & П.П. Соколов. Тройка \\
\hline 6362 & $\begin{array}{l}\text { Петр Соколов. Тройка. } \\
\text { Акварель. }\end{array}$ & Г-3918 & П.П. Соколов. Тройка \\
\hline \multicolumn{4}{|c|}{ Разные вещи } \\
\hline 6363 & $\begin{array}{l}\text { Две вазы новые зеленого } \\
\text { цвета с рельефными } \\
\text { украшениями из роз }\end{array}$ & - & $\begin{array}{l}\text { Выдан в студию № ИЗО. } \\
\text { Хранитель музея Д. Прокопьев }\end{array}$ \\
\hline 6364 & $\begin{array}{l}\text { Тарелка зеленая с рельефными } \\
\text { украшениями из роз } \\
\text { современного рыночного } \\
\text { производства }\end{array}$ & - & $\begin{array}{l}\text { Выдан в студию № ИЗО. } \\
\text { Хранитель музея Д. Прокопьев }\end{array}$ \\
\hline 6365 & $\begin{array}{l}\text { Люстра новая венецианского } \\
\text { стекла (цветного) в виде } \\
\text { золоченой корзины с } \\
\text { виноградом и цветами, 40-е гг. } \\
\text { XIX в. }\end{array}$ & П-2178 & $\begin{array}{l}\text { Конец XIX в. Богемия (?). } \\
\text { Неизвестный стеклянный завод. } \\
\text { Люстра }\end{array}$ \\
\hline 6366 & $\begin{array}{l}\text { Бра венецианского стекла к } \\
\text { люстре № } 6365\end{array}$ & $\begin{array}{l}\Pi-1359 / 1 \\
\Pi-1359 / 2\end{array}$ & Конец XIX в. Богемия (?). Два бра \\
\hline 6367 & $\begin{array}{l}\text { Чайник новый посеребренный } \\
\text { (фарфоровый) }\end{array}$ & П-645 & XIX в. Европа. Чайник \\
\hline 6368 & $\begin{array}{l}\text { Ваза каменная стиля Empire, } \\
\text { обвитая по краю гроздьями и } \\
\text { листьями винограда на } \\
\text { колонной подставке }\end{array}$ & П-2247 & Ваза. Камень (кавказский) \\
\hline 6369 & $\begin{array}{l}\text { Два черных медальона } \\
\text { Vittorio-Emmanuelle и } \\
\text { Garibaldi // Доп. список 725, } \\
726\end{array}$ & $\begin{array}{l}\text { 1) } \Gamma-2865 \\
\text { 2) } \Gamma-2866\end{array}$ & $\begin{array}{l}\text { 1) Италия. Неизвестный } \\
\text { художник. } 1859 \text { г. Медальон. } \\
\text { Портрет Виктора Эммануила II, } \\
\text { короля Италии; 2) утрачен }\end{array}$ \\
\hline 6370 & $\begin{array}{l}\text { Приписывается Pietro Gottardo } \\
\text { Gonsaque. Три маленьких } \\
\text { круглых медальона }\end{array}$ & $\begin{array}{l}\Gamma-2865 \\
\Gamma-2866\end{array}$ & $\begin{array}{l}\text { Архитектурные мотивы. } \\
\text { (Один медальон при передаче } \\
\text { музея в } 1921 \text { г. не найден. } \\
\text { Д. Прокопьев) }\end{array}$ \\
\hline
\end{tabular}




\begin{tabular}{|c|c|c|c|}
\hline 6371 & $\begin{array}{l}\text { Боярский маскарадный } \\
\text { костюм новый распоротый // } \\
\text { Доп. список } 22\end{array}$ & ВП-563 & $\begin{array}{l}\text { Два куска материи (шелк) } \\
\text { (старый инв. № ДСП 22) }\end{array}$ \\
\hline 6372 & $\begin{array}{l}8 \text { кофейных чашек и } 9 \text { блюдец } \\
\text { фабрики Гарднер белых с } \\
\text { позолотой и синим ободком / } \\
\text { при проверке найдено } 5 \text { чашек } \\
\text { с блюдцем. Не найдено } \\
3 \text { чашки и } 4 \text { блюдца }\end{array}$ & - & $\begin{array}{l}\text { Не удалось идентифицировать } \\
\text { (м.б., записаны два раза??? 6329?) }\end{array}$ \\
\hline 6373 & $\begin{array}{l}\text { Два молочника фабрики } \\
\text { А. Попова, один синего, } \\
\text { другой зеленого цвета, } \\
\text { расписанных цветами мака. } \\
\text { Ручки в виде кораллов. Марка } \\
\text { подглазурная синяя. }\end{array}$ & $\begin{array}{l}\text { П-486/1 } \\
\text { П-486/2 }\end{array}$ & $\begin{array}{l}\text { Завод Попова. 1840-1850 гг. } \\
\text { Два кувшина }\end{array}$ \\
\hline 6374 & $\begin{array}{l}\text { Ромео и Джульетта. Вышивка, } \\
\text { 30-40-е гг. ХІХ в. } \\
\text { (шерстями) // Доп. список } 170\end{array}$ & ВП-505 & $\begin{array}{l}\text { Россия. Первая половина XIX в. } \\
\text { Ромео и Джульетта }\end{array}$ \\
\hline 6375 & $\begin{array}{l}\text { Грехопадение. Барельеф } \\
\text { круглый из слоновой кости }\end{array}$ & CK-157 & $\begin{array}{l}\text { П.Ж. Гайрар. Вторая половина } \\
\text { ХІХ в. Франция. Дафнис и Хлоя }\end{array}$ \\
\hline 6376 & $\begin{array}{l}\text { Неизвестный художник } \\
\text { XVIII в. Портрет императора } \\
\text { Петра I. Масло, холст }\end{array}$ & Ж-601 & $\begin{array}{l}\text { Россия, XVIII в. } \\
\text { Портрет Петра I }\end{array}$ \\
\hline 6377 & $\begin{array}{l}\text { Schäffer. Опушка леса со } \\
\text { скачущими всадниками. } \\
\text { Масло, холст // Передана во } \\
\text { временное пользование } \\
\text { танкистской школе. } \\
\text { А.В. и В.В. Леонтьевы }\end{array}$ & - & $\begin{array}{l}\text { Франция, середина XIX в. } \\
\text { Охота }\end{array}$ \\
\hline 6378 & $\begin{array}{l}\text { Портрет неизвестного с двумя } \\
\text { мальчиками. Масло, холст }\end{array}$ & - & $\begin{array}{l}\text { Передан в Музей ФОН } \\
\text { Саратовского университета } \\
20 \text { апреля } 1922 \text { г. Хранитель } \\
\text { музея Д. Прокопьев }\end{array}$ \\
\hline 6379 & $\begin{array}{l}\text { Юлий Клевер. Летний пейзаж. } \\
\text { Масло, холст }\end{array}$ & - & $\begin{array}{l}\text { Передана во временное } \\
\text { пользование в Дом работников } \\
\text { просвещения. } \\
\text { Список от } 15 / \mathrm{X}-24 \text { г. }\end{array}$ \\
\hline
\end{tabular}

Статья поступила в редакцию 12.02.2021 г. 